Article

\title{
From Phenology and Habitat Preferences to Climate Change: Importance of Citizen Science in Studying Insect Ecology in the Continental Scale with American Red Flat Bark Beetle, Cucujus clavipes, as a Model Species
}

\author{
Radomir Jaskuła ${ }^{1, *(\mathbb{D})}$, Marta Kolanowska ${ }^{2,3} \mathbb{D}$, Marek Michalski ${ }^{4} \mathbb{D}$ and Axel Schwerk ${ }^{5} \mathbb{D}$ \\ 1 Department of Invertebrate Zoology and Hydrobiology, Faculty of Biology and Environmental Protection, \\ University of Lodz, Banacha 12/16, 90-237 Łódź, Poland \\ 2 Department of Geobotany and Plant Ecology, Faculty of Biology and Environmental Protection, \\ University of Lodz, Banacha 12/16, 90-237 Łódź, Poland; marta.kolanowska@biol.uni.lodz.pl \\ 3 Department of Biodiversity Research, Global Change Research Institute AS CR, 60300 Brno, Czech Republic \\ 4 Department of Experimental Zoology and Evolutionary Biology, Faculty of Biology and \\ Environmental Protection, University of Lodz, Banacha 12/16, 90-237 Łódź, Poland; \\ marek.michalski@biol.uni.lodz.pl \\ 5 Department of Landscape Art, Institute of Environmental Engineering, Warsaw University of Life \\ Sciences-SGGW, Nowoursynowska 166, 02-787 Warsaw, Poland; axel_schwerk@sggw.edu.pl \\ check for \\ updates \\ * Correspondence: radomir.jaskula@biol.uni.lodz.pl
}

Citation: Jaskuła, R.; Kolanowska, M.; Michalski, M.; Schwerk, A. From Phenology and Habitat Preferences to Climate Change: Importance of Citizen Science in Studying Insect Ecology in the Continental Scale with American Red Flat Bark Beetle, Cucujus clavipes, as a Model Species. Insects 2021, 12, 369. https://doi.org/ $10.3390 /$ insects 12040369

Academic Editors:

Cristina Castracani and

Alessandro Campanaro

Received: 22 March 2021

Accepted: 17 April 2021

Published: 20 April 2021

Publisher's Note: MDPI stays neutral with regard to jurisdictional claims in published maps and institutional affiliations.

Copyright: (c) 2021 by the authors. Licensee MDPI, Basel, Switzerland. This article is an open access article distributed under the terms and conditions of the Creative Commons Attribution (CC BY) license (https:// creativecommons.org/licenses/by/ $4.0 /)$.
Simple Summary: Studies of widely distributed species often are problematic as such research usually needs to engage a lot of time, a large team of field workers, and big financial support before good quality data will be collected. Citizen scientists allow to study different aspects of species biology and ecology with significantly reduced basic operational costs of such studies. Based on the data deposited in the iNaturalist database, we studied the ecology of the American flat bark beetle in the entire area of its species range. The results clearly show high value of citizen science, particularly in studies focused on habitat preferences and phenology in both recognized subspecies of this taxon.

Abstract: The American red flat bark beetle, Cucujus clavipes, is a wide distributed saproxylic species divided into two subspecies: ssp. clavipes restricted to eastern regions of North America and ssp. puniceus occurring only in western regions of this continent. Unique morphological features, including body shape and body coloration, make this species easy to recognize even for amateurs. Surprisingly, except some studies focused on physiological adaptations of the species, the ecology of $C$. clavipes was almost unstudied. Based on over 500 records collected by citizen scientists and deposited in the iNaturalist data base, we studied phenological activity of adult beetles, habitat preferences and impact of future climate change for both subspecies separately. The results clearly show that spp. clavipes and ssp. puniceus can be characterized by differences in phenology and macrohabitat preferences, and their ranges do not overlap at any point. Spp. clavipes is found as more opportunistic taxon occurring in different forests as well as in urban and agricultural areas with tree vegetation always in elevations below $500 \mathrm{~m}$, while elevational distribution of ssp. puniceus covers areas up to $2300 \mathrm{~m}$, and the beetle was observed mainly in forested areas. Moreover, we expect that climate warming will have negative influence on both subspecies with the possible loss of proper niches at level even up to $47-70 \%$ of their actual ranges during next few decades. As the species is actually recognized as unthreatened and always co-occurs with many other species, we suggest, because of its expected future habitat loss, to pay more attention to conservationists for possible negative changes in saproxylic insects and/or forest fauna in North America. In addition, as our results clearly show that both subspecies of $C$. clavipes differ ecologically, which strongly supports earlier significant morphological and physiological differences noted between them, we suggest that their taxonomical status should be verified by molecular data, because very probably they represent separate species. 
Keywords: Coleoptera; Cucujidae; North America; USA; Canada; phenological activity; macrohabitat preferences; habitat loss; citizen scientific data; iNaturalist

\section{Introduction}

The citizen science (known also as "online citizen science", "community science", and/or "volunteer monitoring") is often defined as a scientific research conducted, at least in part, by nonprofessional and/or amateur scientists [1,2]. Even if it has a long history in the ecological sciences and has made important contributions to science, education, and society [3-6], the term appeared relatively recently in the scientific world but very quickly started to play a very important role in the scientific community all over the world. Although different environmental sciences use the data collected by citizen scientists, most probably the highest influence of this activity is observed in studies focused on biodiversity and distribution of fungi, plants, and land animals including insects. In the literature, there are numerous examples where observations by citizen scientists allow to assess, monitor, and predict biodiversity on local, regional, country, continental, or global scale, e.g., [3,7-14]. In many cases citizen scientists helped, e.g., to delimit the geographical distribution of a species, e.g., $[15,16]$; to find species for the first time in the country, e.g., [17-20], in the continent, e.g., [21-23]; or even to discover new taxa, e.g., [21,24-29]. Moreover, such observations allow to monitor migratory birds, e.g., [30-34]; rare and endangered species, e.g., [35-38]; expansion of pests, e.g., [20,39,40]; or alien and/or invasive species, e.g., [18,22,39,41-51] as well as colonization of new human-made habitats, e.g., [51]. In addition, numerous studies show that data collected by amateur scientists allow to describe new interactions between species, e.g., [17,52], to investigate animal phenology, e.g., [53], and behavior, e.g., [54], to find changes in species abundance and demography, e.g., [55-57], and other threats for local fauna and flora being important for nature conservation, e.g., [8,58-65].

Besides many local, regional, or national programs and initiatives focused on biodiversity studies for which help and support by citizen scientists is crucial, numerous online databases or even social media play a very important role in collecting citizen scientific data [66]. Some of these webpages are strictly focused on a single taxonomic group, e.g., eBird.org on birds, AntWeb.org on ants, or BugGuide.Net on insects and other terrestrial arthropods, while others like Zooniverse or iNaturalist accept records of all animals or organisms living on the Earth respectively. Among all mentioned projects, the iNaturalist, with its 37 language versions, over 3.5 million total registered users, and over 66 million observations, is currently the most popular citizen science website. As a consequence, numerous scientific papers based at least partly on these records are published every year, e.g., $[8,11,13,14,23,24,27,29,38,39,50,53,59,65,67-72]$.

Although citizen science data play a crucial role in numerous biodiversity and ecological studies, it is important to note that sometimes they are justifiably criticized for selective reporting, uneven sampling, incomplete detection, or-crucial for future use of such data-for species misidentification. The last of the mentioned problems often appears in case of records based on photographs and is observed, e.g., in cases of poor picture quality or resolution or improper orientation of the photographed object, which is especially common in the case of invertebrates including many insects. As a result, usually the best data are available for species which can be easily identified, including taxa characterized by medium and/or big body size, diurnal activity, vivid body coloration, and/or unique body shape as it is often observed in butterflies, dragonflies, or some beetles.

The flat bark beetles (Coleoptera: Cucujidae) are a small insect family with only about 70 species distributed worldwide except Africa, polar regions, and numerous oceanic islands [23,73-86]. Among them, only members of genera Cucujus Fabricius, 1775, and Pediacus Shuckard, 1839, are known from North America, with the single species, Cucujus clavipes Fabricius, 1781, representing the first genus $[76,77,86]$. The species is recorded from Canada and the USA, and its identification is rather easy because of very characteristic 
vivid red body coloration, unique strongly flattened body shape, and medium body size. Although currently it is divided into two subspecies (earlier recognized as two separate species), even in the field, their misidentification is rather unlikely as they are geographically separated, with C. c. clavipes Fabricius, 1781, known from eastern part of North America and C. c. puniceus (Mannerheim, 1843) noted only from western regions of this continent $[76,77,86]$. In addition to the wide area occupied by this species, both subspecies of $C$. clavipes are not rare or even very common in most of the species range, which together with very attractive body coloration, make this beetle a common object of field observation, including citizen scientists using their camera to photograph nature. All these features make $C$. clavipes a perfect model for studies focused on insect ecology when help and support of citizen science is planned to be used.

The aim of this paper is to evaluate the role of citizen science, particularly observations done using the iNaturalist website (iNaturalist.org), in studying selected aspects of insect ecology with the American red flat bark beetle, Cucujus clavipes, as a model taxon, including (1) adult phenological activity of its both subspecies distributed in western and eastern parts of North America, (2) habitat preferences of both subspecies, (3) present and future species range for its both subspecies in the context of global climate change. As far as we know, the study is the first case when citizen science is used to study present and future ecology of insect species at the continental scale.

\section{Materials and Methods}

\subsection{Sampling Citizen Scientific Data from iNaturalist}

Although numerous records for Cucujus clavipes are known from the literature $[76,77,86-104]$ and various online resources, such as Global Biodiversity Information Facility (www.gbig.org, accessed on 31 August 2020), all data used in this study were taken directly and only from the iNaturalist data base (www.inaturalist.org, accessed on 31 August 2020). All pictures of American Cucujidae published in the database since its beginning to the end of August 2020 were checked for records of $C$. clavipes. Although the species can be easily recognized based on photographs, to avoid any potential misidentification, we excluded all records with poor picture quality or resolution and/or insufficient orientation of the photographed beetles. We also excluded observations lacking detailed GPS collecting data. As a result, almost 600 pictures were verified of which a few dozen were excluded. Finally, in total, 548 records including 368 for ssp. clavipes (observations from 1986 to 2020) and 180 for spp. puniceus (observations from 2009 to 2020) were amassed (Figure 1, Data S1). For all these data locality, date of observation and GPS coordinates were collected.

\subsection{Phenology of Adults}

As almost all records published in the iNaturalist database include photographs of only a single individual, each observation by citizen scientist was accepted as a single record. To examine any differences in phenological activity between the subspecies of C. clavipes, which potentially would be supported by their geographical separation, ssp. clavipes and ssp. puniceus were analyzed separately. In this analysis we accepted only records of adult beetles and with full date of observation.

\subsection{Habitat Preferences}

To analyze elevational distribution of the Cucujus clavipes subspecies the original CSV file downloaded directly from the iNaturalist, including GPS coordinates of each record, was converted into ESRI shapefile ( ${ }^{*}$.SHP) using online MyGeodata software by the GeoCzech, Inc. (https:/ / mygeodata.cloud/converter/csv-to-shp, accessed on 1 September 2020) and accepting World Geodetic System WGS 84 (EPSG:4326) as coordinate system. As a source of altitude data, we used a GeoTIFF raster file derived from SRTM15+ project. Horizontal resolution of the raster was 15 Arc Sec what corresponds to $0.5 \times 0.5 \mathrm{~km}$ on the equator while accuracy of altitude was $1 \mathrm{~m}$ [105]. The GeoTIFF raster file was taken 
from the Open Topography (portal.opentopography.org, accessed on 17 February 2021). To connect GPS coordinates to altitudinal data, the function "sample raster values" of QGIS v.3.10, was used (QGIS.org, accessed on 17 February 2021). Graphs illustrating Cucujus clavipes altitudinal distribution were prepared with R v.4.0.3 [106] with ggplot2 v.3.3.3 library [107].

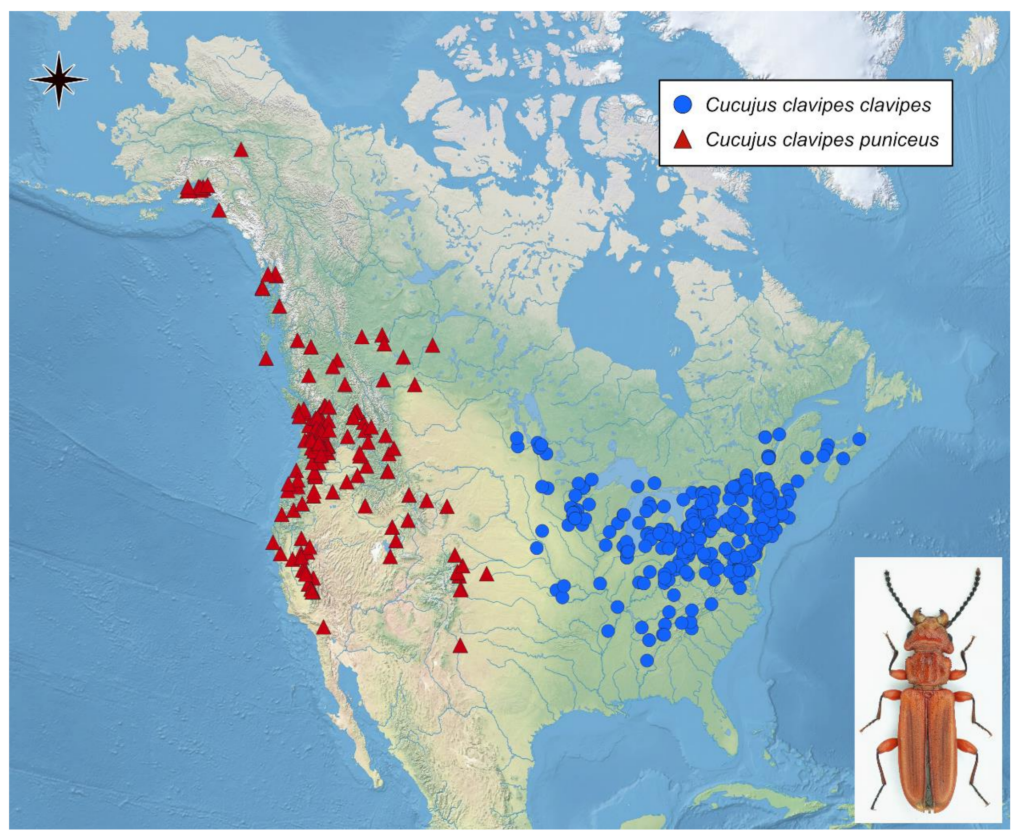

Figure 1. Location of Cucujus clavipes records based on observation by citizen scientists published on iNaturalist.org and used in this study (picture shows spp. clavipes; phot. M. Michalski.

To analyze macrohabitat preferences of the Cucujus clavipes subspecies, the Global Land Cover by National Mapping Organizations ver. 3 (GLCNMO; https:/ / globalmaps. github.io/glcnmo.html, accessed on 10 December 2020) was used.

In order to study if variation in environmental parameters on the plots reflects the presence of the subspecies, a Principal Components Analysis (PCA) was carried out using Canoco for Windows 4.56 [108,109]. The environmental variables: solar radiation in December (SRD), which is the month with the shortest days; solar radiation in June (SRJ), which is the month with the longest day; mean annual temperature $\left({ }^{\circ} \mathrm{C}\right)(\mathrm{MAT})$; maximum temperature of the warmest month $\left({ }^{\circ} \mathrm{C}\right)(\mathrm{MTWM})$; minimum temperature of the coldest month $\left({ }^{\circ} \mathrm{C}\right)(\mathrm{MTCM})$; annual precipitation $(\mathrm{mm})(\mathrm{AP})$; and altitude above sea level $(\mathrm{m})$ (ASL) were included in this analysis. These data were downloaded from WorldClim v. 2.1 with the resolution of 10 arc-minutes based on GPS coordinates of each record. As these variables were measured in different units, centering and standardization were applied and the data were $\log$ transformed $(\log (y+1)$, because of zero values).

\subsection{Impact of Climate Change}

Gathered records of C. clavipes clavipes ( 368 records) and C. c. puniceus (180 records) were rarified using 5 classes of habitat heterogeneity and a minimum distance of $10 \mathrm{~km}$ as calculated in SDMtoolbox 2.3 for ArcGIS [110]. The final database of localities included 90 records of ssp. clavipes and 84 of subsp. puniceus (Figure 2, Data S1). 


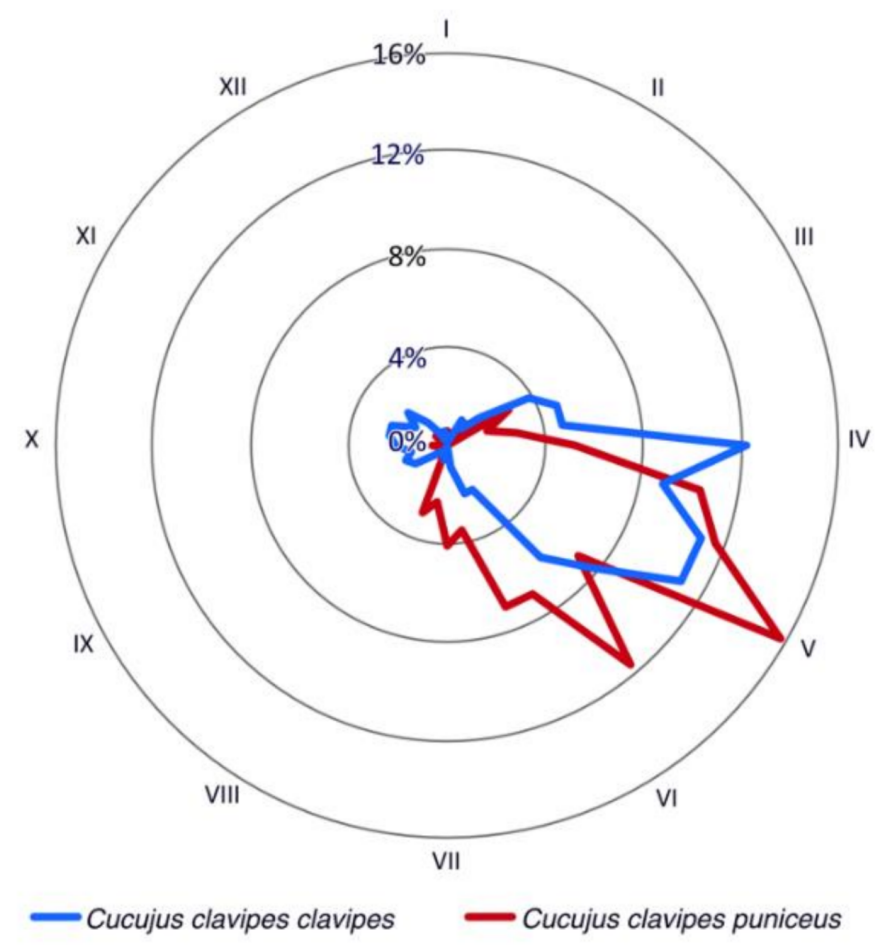

Figure 2. Phenological activity of adult Cucujus clavipes subspecies (particular months of the year are written as Roman numerals).

The ecological niche modelling was done using the maximum entropy method in MaxEnt version 3.3.2 [111-113] based on presence-only observations of the studied subspecies. For the modelling bioclimatic variables in 10 arc-minutes of interpolated climate surface downloaded from WorldClim v. 2.1 [114] were used. Eleven of 19 variables were removed from the analyses due to their high correlation (above 0.9) as calculated in Pearson correlation coefficient (Table 1) computed using SDMtoolbox 2.3 for ArcGIS [110]; only the following eight were used: bio1 (annual mean temperature), bio4 (temperature seasonality (standard deviation $\times 100)$ ), bio6 (min temperature of coldest month), bio9 (mean temperature of driest quarter), bio10 (mean temperature of warmest quarter), bio11 (mean temperature of coldest quarter), bio12 (annual precipitation), bio15 (precipitation seasonality (coefficient of variation)). The other variables used in modelling of current potential range of the studied subspecies were: (1) solar radiation (srad 1-12 (solar radiation in particular month, starting with 1 for January and ending with 12 for December)), (2) soil class (0-acrisols, 1-albeluvisols, 2-alisols, 3-andosols, 4-arenosols, 5-calcisols, 6cambisols, 7-chernozems, 8-cryosols, 9-durisols, 10-ferralsols, 11-fluvisols, 12gleysols, 13-gypsisols, 14-histosols, 15-kastanozems, 16-leptosols, 17-lixisols, 18luvisols, 19-nitisols, 20-phaeozems, 21-planosols, 22-plinthosols, 23-podzols, 24regosols, 25-solonchaks, 26-solonetz, 27-stagnosols, 28-umbrisols, and 29-vertisols), and (3) land cover (1-broadleaf evergreen forest), 2-broadleaf deciduous forest, 3 needleleaf evergreen forest, 4-needleleaf deciduous forest, 5-mixed forest, 6-tree open, 7-shrub, 8-herbaceous, 9-herbaceous with sparse tree/shrub, 10-sparse vegetation, 11-cropland, 12-paddy field, 13-cropland/other vegetation mosaic, 14-mangrove, 15-wetland, 16-bare area, consolidated (gravel, rock), 17-bare area, unconsolidated (sand), 18-urban, 19-snow /ice, 20-water bodies). 
Table 1. Pearson correlation coefficient for 19 bioclimatic variables.

\begin{tabular}{|c|c|c|c|c|c|c|c|c|c|c|c|c|c|c|c|c|c|c|c|}
\hline bio19 & 0.496 & 0.550 & 0.640 & 0.415 & 0.591 & 0.179 & 0.465 & 0.433 & 0.549 & 0.599 & 0.318 & 0.930 & 0.898 & 0.859 & 0.390 & 0.910 & 0.873 & 0.720 & $x$ \\
\hline bio18 & 0.553 & 0.826 & 0.824 & 0.760 & 0.848 & 0.252 & 0.802 & 0.819 & 0.380 & 0.845 & 0.353 & 0.916 & 0.913 & 0.859 & 0.691 & 0.912 & 0.870 & $x$ & \\
\hline bio17 & 0.527 & 0.636 & 0.684 & 0.537 & 0.686 & 0.165 & 0.582 & 0.582 & 0.457 & 0.701 & 0.291 & 0.951 & 0.866 & 0.997 & 0.394 & 0.875 & $x$ & & \\
\hline bio16 & 0.561 & 0.757 & 0.805 & 0.656 & 0.785 & 0.245 & 0.704 & 0.688 & 0.490 & 0.782 & 0.368 & 0.979 & 0.997 & 0.857 & 0.657 & $x$ & & & \\
\hline bio15 & 0.444 & 0.863 & 0.820 & 0.894 & 0.827 & 0.244 & 0.908 & 0.766 & 0.342 & 0.773 & 0.347 & 0.556 & 0.672 & 0.376 & $x$ & & & & \\
\hline bio14 & 0.509 & 0.619 & 0.664 & 0.527 & 0.668 & 0.152 & 0.569 & 0.564 & 0.441 & 0.683 & 0.274 & 0.938 & 0.849 & $x$ & & & & & \\
\hline bio13 & 0.567 & 0.763 & 0.810 & 0.661 & 0.790 & 0.258 & 0.709 & 0.698 & 0.492 & 0.787 & 0.381 & 0.973 & $x$ & & & & & & \\
\hline bio12 & 0.568 & 0.724 & 0.774 & 0.618 & 0.764 & 0.215 & 0.667 & 0.660 & 0.490 & 0.770 & 0.343 & $x$ & & & & & & & \\
\hline bio11 & 0.836 & 0.411 & 0.539 & 0.123 & 0.487 & 0.838 & 0.199 & 0.535 & 0.779 & 0.555 & $x$ & & & & & & & & \\
\hline bio10 & 0.806 & 0.951 & 0.944 & 0.760 & 0.991 & 0.364 & 0.833 & 0.936 & 0.612 & $x$ & & & & & & & & & \\
\hline bio9 & 0.816 & 0.508 & 0.625 & 0.188 & 0.569 & 0.551 & 0.275 & 0.441 & $x$ & & & & & & & & & & \\
\hline bio8 & 0.725 & 0.891 & 0.860 & 0.744 & 0.923 & 0.381 & 0.803 & $x$ & & & & & & & & & & & \\
\hline bio7 & 0.398 & 0.919 & 0.829 & 0.990 & 0.891 & 0.102 & $x$ & & & & & & & & & & & & \\
\hline bio6 & 0.592 & 0.234 & 0.355 & 0.056 & 0.308 & $x$ & & & & & & & & & & & & & \\
\hline bio5 & 0.741 & 0.981 & 0.958 & 0.826 & $x$ & & & & & & & & & & & & & & \\
\hline bio4 & 0.297 & 0.856 & 0.753 & $x$ & & & & & & & & & & & & & & & \\
\hline bio3 & 0.751 & 0.961 & $x$ & & & & & & & & & & & & & & & & \\
\hline bio2 & 0.656 & $x$ & & & & & & & & & & & & & & & & & \\
\hline bio1 & $x$ & & & & & & & & & & & & & & & & & & \\
\hline & bio1 & bio2 & bio3 & bio4 & bio5 & bio6 & bio7 & bio8 & bio9 & bio10 & bio11 & bio12 & bio13 & bio14 & bio15 & bio16 & bio17 & bio18 & bio \\
\hline
\end{tabular}

The data on distribution of soil classes were obtained from Global Soil Information [115] (http: / / www.soilgrids.org, accessed on 20 December 2020) with a $250 \mathrm{~m}^{2}$ resolution and upscaled to fit the resolution and extent of the bioclimatic variables. The data on solar radiation in each month were downloaded from WorldClim v. 2.1 with the resolution of 10 arc-minutes. The Global Land Cover by National Mapping Organizations ver. 3 (GLCNMO) was a source of information about land cover in ENM analyses.

Because some previous studies [116] indicated that usage of a restricted area in ENM analysis is more reliable than calculating habitat suitability on the global scale, the area of the analysis was restricted to $72.91-23.41^{\circ} \mathrm{N}-168.58-48.92^{\circ} \mathrm{W}$. Predictions of the future extent of the climatic niches of studied insect in 2080-20100 were made using climate projections developed by CNRM/CERFACS modelling group for Coupled Model Intercomparison Project (CNRM-CM6-1) for four Shared Socio-economic Pathways ([117] SSPs): 126, 245, 370 and 585. These pathways are trajectories adopted by the Intergovernmental Panel on Climate Change (IPCC). The scenarios offer a broader view of a "business as usual" world without future climate policy, with global warming in 2100 ranging from a low of $3.1^{\circ} \mathrm{C}$ to a high of $5.1^{\circ} \mathrm{C}$ above pre-industrial levels.

In all analyses, the maximum number of iterations was set to 10,000 and convergence threshold to 0.00001 . The neutral $(=1)$ regularization multiplier value and auto features were used. All samples were added to the background. The "random seed" option which provided a random test partition and background subset for each run was applied. Twenty percent of the samples were used as test points. The run was performed as a bootstrap with 100 replicates, and the output was set to logistic. In this analysis, all operations on GIS data were carried out using ArcGis 10.6 (Esri, Redlands, CA, USA). Additionally, to avoid dubious projections, the "fade by clamping" function in MaxEnt was enabled. This precluded extrapolations outside the environmental range of the training data [118]. The evaluation of the created models was made using the area under the curve AUC; $[119,120]$ and True Skill Statistic TSS; [121].

SDMtoolbox 2.3 for ArcGIS [110] was used to visualize changes in the distribution of suitable niches of the studied subspecies caused by the global warming. To compare distribution model created for current climatic conditions with future models all SDMs were converted into binary rasters and projected using the Goode homolosine as projection. 
The presence threshold was estimated based on the median values of grids in which studied species occur in models created using present-time -0.48 for C. c. clavipes and 0.52 for C. c. puniceus.

\section{Results}

\subsection{Activity of Adult Beetles of Cucujus clavipes and C. v. puniceus}

Citizen scientific data show that adult beetles of both Cucujus clavipes subspecies were observed mainly during the spring period (Figure 1). For C. c. clavipes, the highest beetle activity was noted between the end of March/beginning of April and the beginning of May while for C. c. puniceus it was observed between mid-April and mid-June. In case of C. c. clavipes, the second, significantly smaller peak, was noted also between the end of September until mid-October (Figure 2).

\subsection{Environmental Parameters vs. Present Distribution of Cucujus clavipes Subspecies}

The subspecies of Cucujus clavipes differ significantly according to elevational distribution. C. c. clavipes was found as lowland-highland species with $95 \%$ of localities located from the sea level up to $500 \mathrm{~m}$ a.s.l. while C. c. puniceus can be characterized by wider elevational range with $95 \%$ of localities placed from the sea level up to $2300 \mathrm{~m}$ a.s.1. (Figures 3 and 4). In addition, C. c. clavipes has narrower geographical range and occupies areas between $30^{\circ}$ and $50^{\circ} \mathrm{N}$ while C. c. puniceus can be found mainly between $30^{\circ}$ and $63^{\circ} \mathrm{N}$ (Figure 4 ).

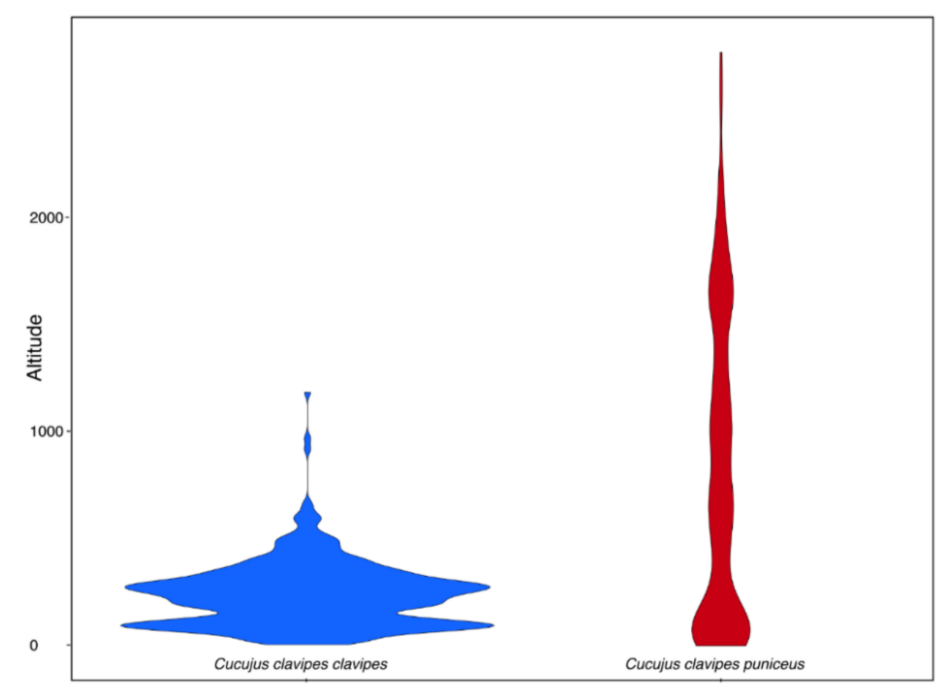

Figure 3. Elevational distribution of Cucujus clavipes clavipes $(n=368)$ and C. c. puniceus $(n=180)$.

Analyses of observations made by iNaturalist citizen scientists show that both subspecies of Cucujus clavipes can be found in various types of macrohabitats including both natural and disturbed areas. In case of C. c. clavipes about $40 \%$ of records come from forests while almost $50 \%$ from habitats changed by human activity, including agricultural areas where different tree species are growing (ca. $40 \%$ ) and urban places (ca. 10\%). In contrast about $50 \%$ records for C. c. puniceus come from various forest types, $10 \%$ from open areas with tree and shrub species while agricultural and urban areas are not preferred by this subspecies (Figure 5). 


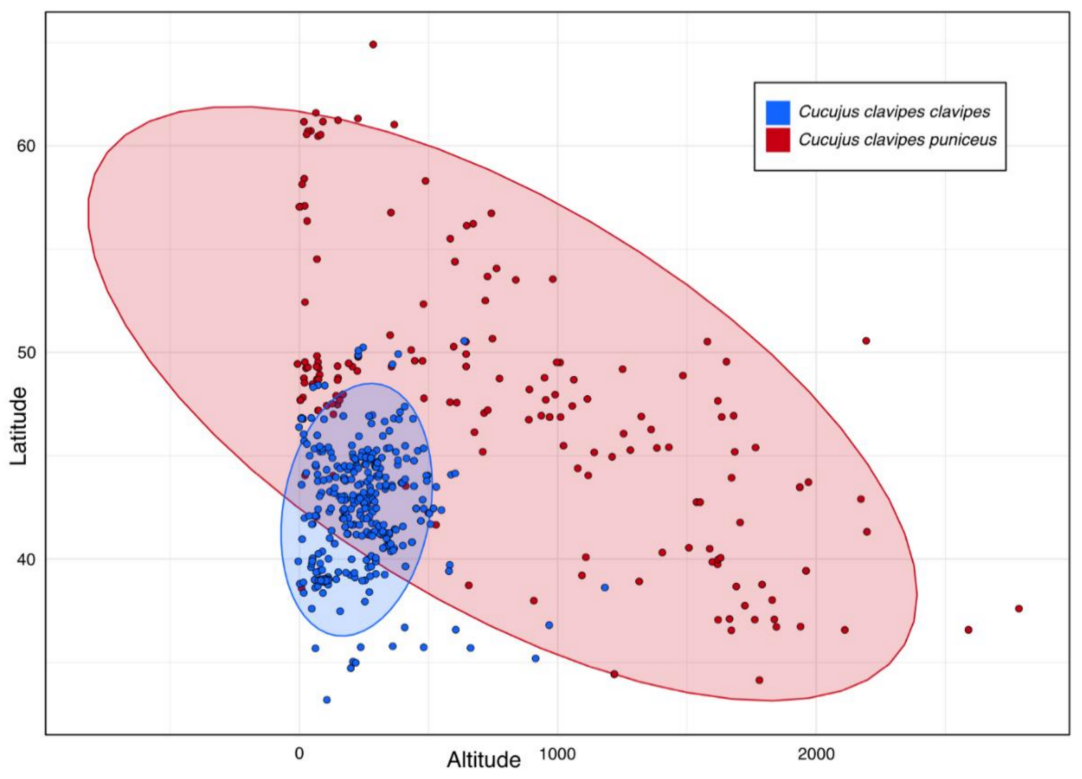

Figure 4. Distribution of Cucujus clavipes clavipes and C. c. puniceus along elevational and geographic gradients. Elipses include $95 \%$ of localities.

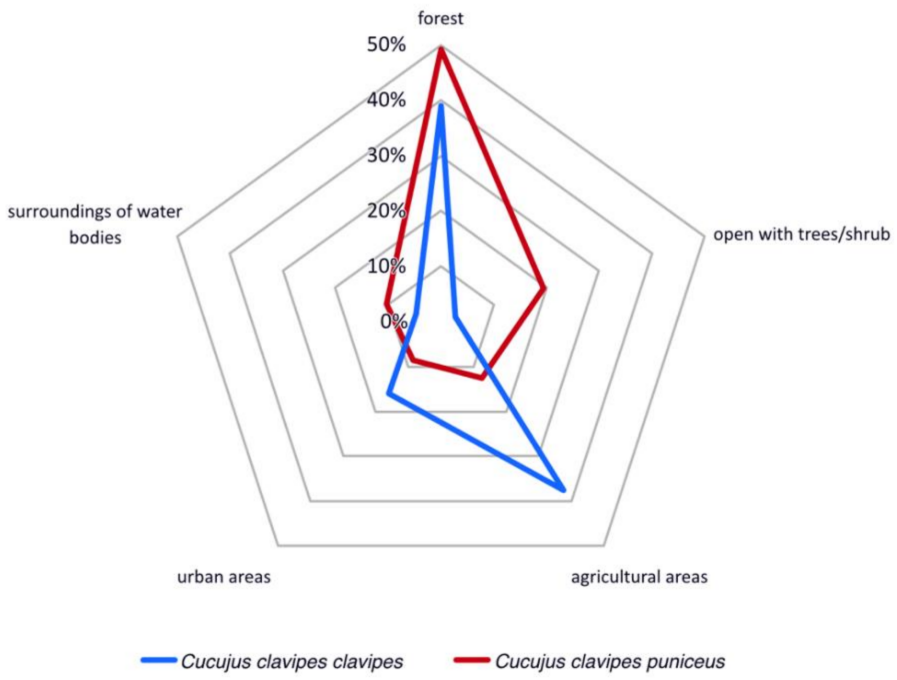

Figure 5. Macrohabitat preferences of Cucujus clavipes subspecies based on citizen scientific data.

The Principal Components Analysis made for environmental variables shows that the first and second ordination axes of the PCA (Figure 6) explained $43.0 \%$ and $24.2 \%$ of the variation in the dataset, respectively. Sites occupied by C. clavipes clavipes are more tightly distributed and located in the center and the bottom left part of the PCA diagram, whereas those occupied by C. c. puniceus are more loosely scattered and located mainly in the remaining three quarters of the diagram. The former are more positively correlated with annual mean temperature (AMT), mean temperature in the warmest month (MTWM), solar radiation in December (SRD), and mean temperature in the coldest month (MTCM) when compared to the latter. Some sites occupied by ssp. puniceus are positively correlated with solar radiation in June (SRJ) and altitude above sea level (ASL) and annual precipitation $(\mathrm{AP})$, respectively. 


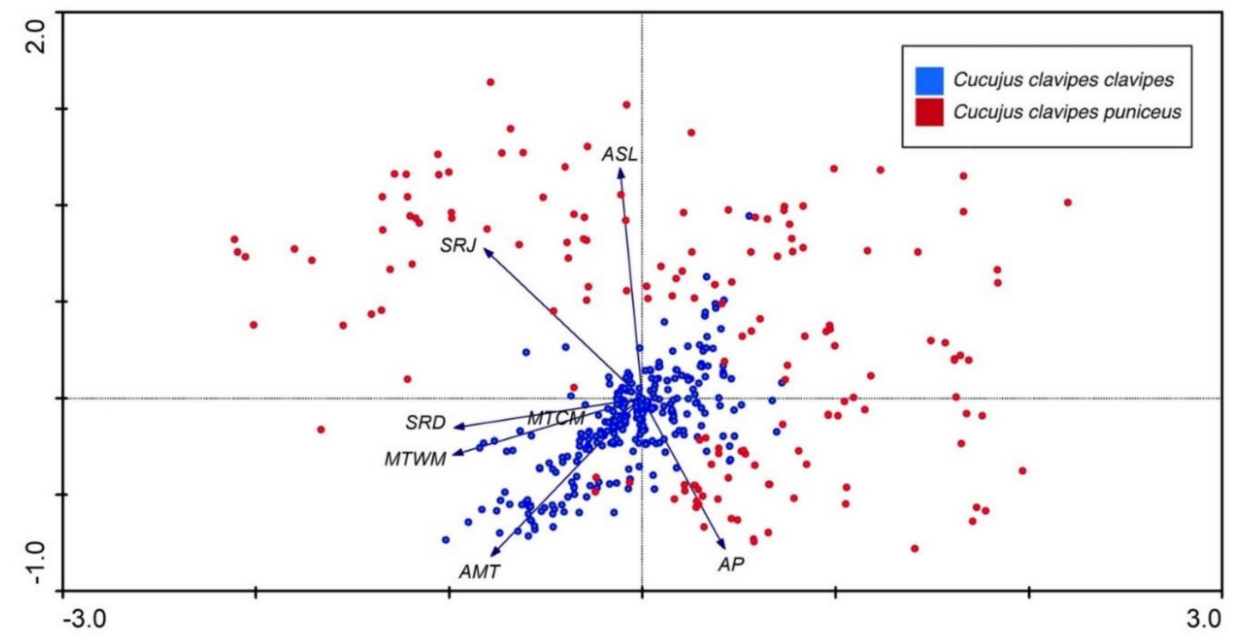

Figure 6. Results of PCA analysis for both subspecies of Cucujus clavipes. Environmental symbols: AMT—annual mean temperature, AP—annual precipitation, ASL—altitude above sea level, MTCMminimum temperature of coldest month, MTWM-maximum temperature of warmest month, SRD—solar radiation in December, SRJ—solar radiation in June.

3.3. ENM-Models Evaluation, Limiting Factors and Range Overlap between Subspecies and Impact of Global Warning

Both models of current distribution of suitable niches of the studied subspecies received high scores of both AUC (subsp. clavipes-0.983, subsp. puniceus-0.967) and TSS (C. c. clavipes-0.923, C. c. puniceus-0.852) statistics which indicates high reliability of the analyses.

As calculated in ENMTools, the ranges of both subspecies do not overlap at any point (Figure 7).

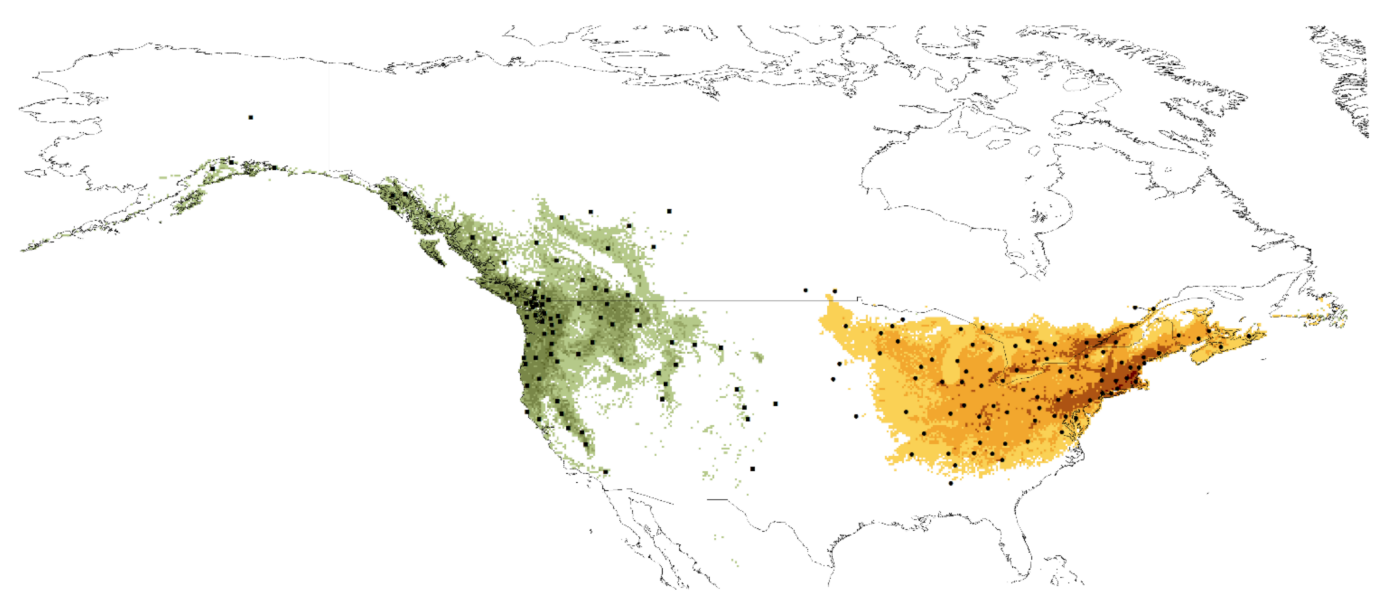

Figure 7. Current distribution of suitable niches of Cucujus clavipes clavipes (orange-brown) and C. c. puniceus (green) and localities used in ENM analyses (dots—subsp. clavipes, squares—subsp. puniceus).

The annual mean temperature (bio1) was the crucial variable influencing models of distribution of the studied insects (Table 2). Both taxa differ, however, in other factors shaping their ranges (Table 2). 
Table 2. Relative contributions of the environmental variables to the Maxent model.

\begin{tabular}{cccc}
\hline \multicolumn{2}{c}{ Cucujus clavipes clavipes } & \multicolumn{2}{c}{ Cucujus clavipes puniceus } \\
\hline Variable & $\begin{array}{c}\text { Percent } \\
\text { Contribution }\end{array}$ & Variable & $\begin{array}{c}\text { Percent } \\
\text { Contribution }\end{array}$ \\
\hline bio1 & 44.3 & bio1 & 35.9 \\
\hline bio12 & 23.9 & bio9 & 20.2 \\
\hline srad07 & 7.8 & land cover & 10.6 \\
\hline srad12 & 7.3 & bio10 & 10.4 \\
\hline bio6 & 4.3 & soil class & 5.6 \\
\hline
\end{tabular}

\subsection{Impact of Global Warming}

As a result of global warming, both studied subspecies will face significant habitat loss (Figures 8 and 9, Table 3). For ssp. clavipes, the most damaging will be ssp126 scenario in which the predicted loss of suitable niches will be $70.13 \%$. In the best-case scenario (ssp370) this taxon will lose $26.65 \%$ of niches. Most of habitat loss will be observed in the western part of the current geographical range of the subspecies. For ssp. puniceus, the most damaging will be ssp585 scenario in which the predicted loss of suitable niches will be $47.10 \%$. The loss will be observed mostly in the southern and eastern part of the subspecies' range. In the best-case scenario (ssp370) this taxon will lose $26.42 \%$ of niches.

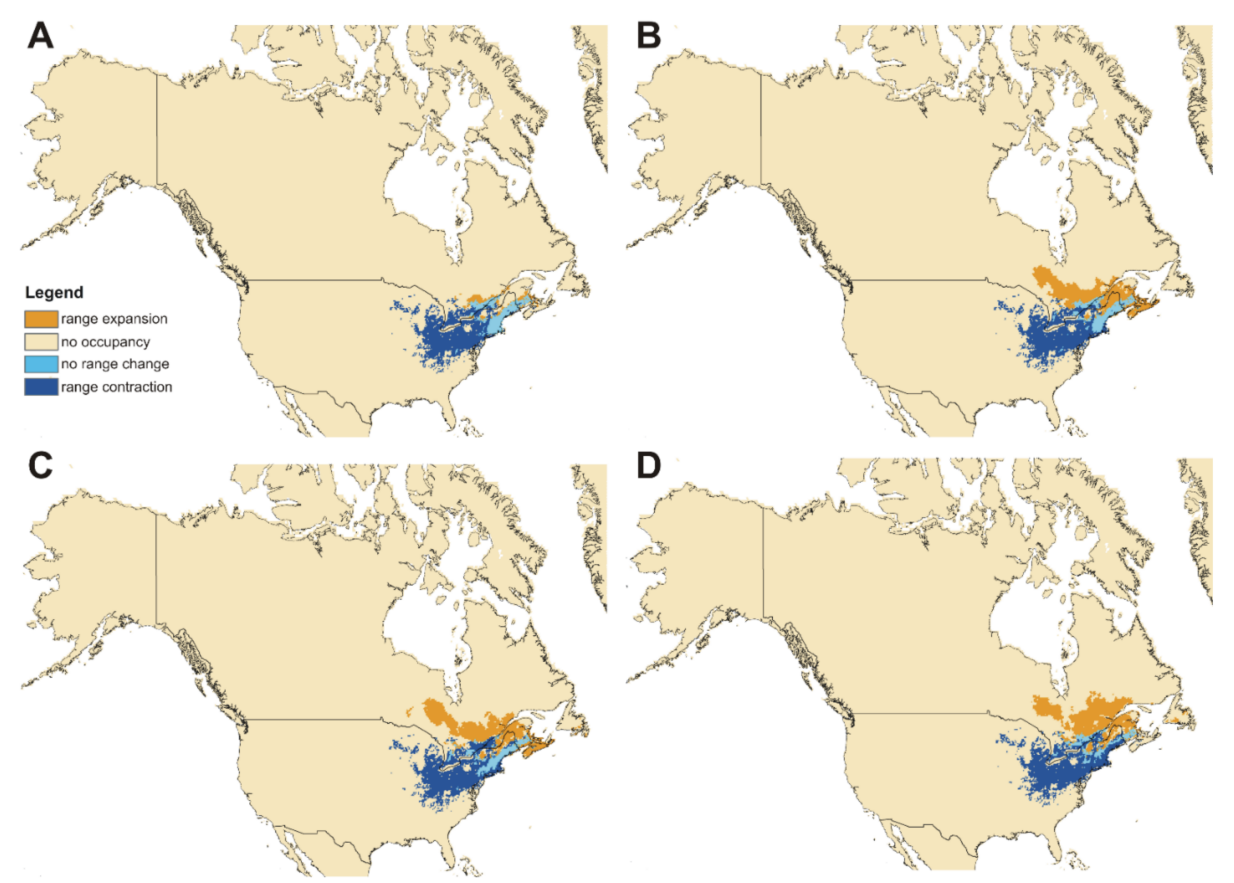

Figure 8. Future changes in the distribution of suitable niches of Cucujus clavipes clavipes according to ssp126 (A), ssp245 (B), ssp370 (C), ssp585 (D) climate change scenarios.

Both subspecies will also gain some niches in the areas where currently climatic conditions are not suitable for them. C. c. clavipes will have a chance to migrate northeastern from the current range while new areas for ssp. puniceus will be available mostly along the Alexander Archipelago and southern Alaska Peninsula. 

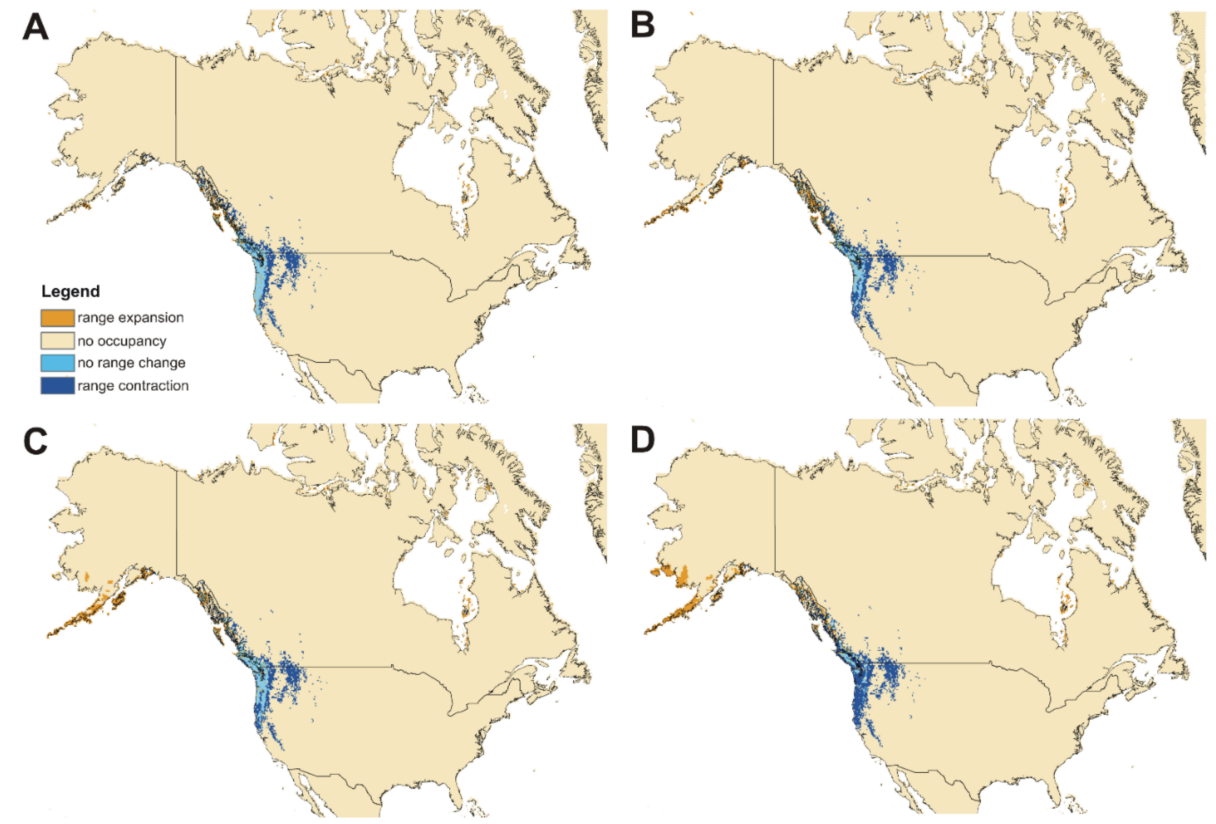

Figure 9. Future changes in the distribution of suitable niches of subsp. puniceus according to ssp126 (A), ssp245 (B), ssp370 (C), ssp585 (D) climate change scenarios.

Table 3. Future changes in coverage of suitable niches of studied taxa $\left[\mathrm{km}^{2}\right]$.

\begin{tabular}{cccccc}
\hline \multicolumn{5}{c}{ Cucujus clavipes clavipes } \\
\hline scenario & -1 (range expansion) & 0 (absent in both) & 1 (present in both) & 2 (range contraction) & Change \\
\hline ssp126 & $92,386.29$ & $19,997,564$ & $204,237.6$ & $788,769.7$ & $-70.13 \%$ \\
\hline ssp245 & $518,292.9$ & $19,571,658$ & $192,326.2$ & $800,681.2$ & $-28.44 \%$ \\
\hline ssp370 & $569,134.4$ & $19,520,816$ & $159,206.6$ & $833,800.8$ & $-26.65 \%$ \\
\hline ssp585 & $580,755.3$ & $19,509,195$ & $133,059.5$ & $859,947.8$ & $-28.12 \%$ \\
\hline scenario & -1 (range expansion) & 0 (absent in both) & 1 (present in both) & 2 (range contraction) & Change \\
\hline ssp126 & $109,236.6$ & $20,422,890$ & $210,338.6$ & $340,492.9$ & $-41.98 \%$ \\
\hline ssp245 & $161,530.7$ & $20,370,596$ & $175,766.4$ & $375,065.1$ & $-38.77 \%$ \\
\hline ssp370 & $213,824.9$ & $20,318,301$ & $191,454.6$ & $359,376.9$ & $-26.42 \%$ \\
\hline ssp585 & $218,763.8$ & $20,313,363$ & $72,630.73$ & $478,200.7$ & $-47.10 \%$ \\
\hline
\end{tabular}

\section{Discussion}

\subsection{Phenological Activity of Cucujus clavipes Subspecies}

Although both taxa currently considered as subspecies of Cucujus clavipes were described over 170 years ago [86,87] and there are at least several papers providing diverse data for them $[76,77,86-104]$, phenological activity of these subspecies was never studied. Our paper provides the first comprehensive phenological data for both C. c. clavipes and C. c. puniceus from the entire area of their ranges. Moreover, this is the only such study for Cucujidae of North America. In addition, until now, only one more species, C. cinnaberinus (Scopoli, 1763), was studied according to phenological activity, but in contrast to our paper, the data for this European species were analyzed only for some small parts of species range, particularly for populations from central Europe [122,123].

Although both subspecies of Cucujus clavipes are active during the spring period, the phenological activity of ssp. clavipes and spp. puniceus is different. The eastern one, ssp. clavipes, which occurs only up to $500 \mathrm{~m}$ a.s.l., starts its activity about two weeks 
earlier compared to the western ssp. puniceus which is known from higher elevations even up to $2300 \mathrm{~m}$ a.s.l. Moreover, in the "mountain" spp. puniceus, the main peak of its phenological activity ends about half of month later than it is observed in the "lowland" spp. clavipes. Such differences in phenological activity of both subspecies can be clearly explained when we note that insects are poikilothermic animals, and their activity strongly depends on the temperature of the surrounding environment, e.g., [124,125], while the average temperature in the temperate climate zone is followed by length of total day and is strongly correlated with altitude. Although different biotic and abiotic factors should be taken into consideration, there are numerous studies showing that mountainous insect species tend to start their activity later than their lowland relatives, which is especially well observed in vernal taxa, e.g., [126-134].

Except for the main peaks of phenological activity of adult beetles, a smaller one was noted in the "lowland" spp. clavipes. Although more data about its life cycle and life span are needed, most probably the "second peak" is a result of activity of beetles that finished the life cycle during the summer period and occasionally left their shelters under the bark, most probably because of unexpected higher temperature during the autumn. Similar observations are known for single specimens of European Cucujus species [122,135]. On the other hand, we cannot exclude that the autumn peak in the phenological activity of C.c. clavipes is connected to the climate warming as similar changes in insect activity/phenology have been noted in many species all around the world, e.g., [136-149].

\subsection{Habitat Preferences of Cucujus clavipes}

Although it is known that Cucujus clavipes clavipes occurs in the eastern regions of North America, from Alaska to California, while C. c. puniceus occupies western parts of this continent, from Quebec to Alabama [76,77], and both taxa can be characterized by significant differences in physiological adaptations [90,91,95,99-103], and as a consequence need to be characterized by different preferences according to habitat parameters at least in some aspects, surprisingly, no study has been focused on habitat preferences of these beetle taxa. Our study, thanks to the citizen scientific data deposited in the iNaturalist database, allowed to fill this gap and find that ecological niches of $C$. clavipes subspecies do not overlap even if sometimes both taxa can be found in similar types of macrohabitats. $C$. c. clavipes was found to be a subspecies characterized not only by smaller geographic range, but also its altitudinal distribution is significantly narrower in compare to C. c. puniceus (Figures 3, 4 and 7). On the other hand, C. c. puniceus seems to prefer mainly various forests, and such types of habitats are known for this subspecies from the literature $[92,93,96]$, which can suggest higher habitat specialization in this taxon. At the same time, it can be characterized by being significantly less specific according to studied abiotic factors including, e.g., annual precipitation or annual temperature when compared to C.c. clavipes (Figure 6). However, this result can be explained by the wider geographical and particularly wider altitudinal distribution of C. c. puniceus, because climatic parameters of a given site should depend to a high degree on its altitude. Accordingly, sites of C. c. clavipes, which are largely restricted to elevations up to $500 \mathrm{~m}$ a.s.l., are positively correlated with mean annual temperature and mean temperature in the warmest month. Surprisingly, C. c. clavipes seems to be a much more opportunistic taxon found not only in different types of forests but also in open areas or even in anthropogenically transformed macrohabitats as agricultural areas or urban areas with tree and/or tree/shrub vegetation. It is interesting that literature data from Nova Scotia, Canada, suggest high habitat specialization of this subspecies as it was found only in coniferous stands in old-growth (120+ years) forests [97].

Although we were able to provide some data about macrohabitat preferences of both Cucujus clavipes subspecies, it was not possible to analyze microhabitat data for these taxa including tree species and the dimensions of tree trunks inhabited by larvae. In the literature, one can find that all stages of Cucujus clavipes are recorded under the bark of different coniferous and deciduous tree species $[88,94,150,151]$ but with no details about diameter and length of dead tree. At least some of those factors, which are recognized as 
very important in other Cucujus species, e.g., [152-160], possibly can be crucial also in case of $C$. clavipes.

\subsection{The Future of Cucujus clavipes Because of Climate Change}

The high anthropogenic impact on biodiversity is the fact and rapid and intense environmental changes due to the human activity are currently observed in almost all of ecosystems all over the world, causing species extinction rates to be the highest in the history of Earth [161-163]. The global climate change is recognized as one of the most important factors having negative influence on species diversity, distribution, changes in phenological activity, decline of rare and endangered species or invasion of pests and/or alien taxa, e.g., [164-176].

In the present paper, we used the Ecological Niche Modelling approach to estimate possible changes in the distribution of the suitable niches of widely distributed and actually unthreatened North American saproxylic beetle Cucujus clavipes, checking separately future changes in the ranges of both recognized subspecies. This method has become one of the most important tools for the assessment of the impact of climatic change and has been successfully used, e.g., to evaluate how past climates affected species' distributions, e.g., [177-180] or what will be the effects of future climate changes on species, e.g., [181]. Moreover, it helped to map the future distribution of rare species and/or high modelled species richness allowing to appropriately prioritize conservation areas for the establishment of new protected areas, e.g., [182-185]. In addition, the ENM allowed to determine the potential distribution of species and indicate promising areas for new surveys, e.g., [186-188], to define the distribution of recently described taxa and areas where such species may be found, e.g., $[189,190]$, and/or to indicate areas that are suitable for exotic invasive species to establish new populations, e.g., [191-195]. Our results clearly show that ranges of both subspecies of Cucujus clavipes will significantly change, and depending on scenario, loss of suitable niches for ssp. clavipes will be between $27 \%$ and $70 \%$ while for ssp. puniceus such values are expected at the level of $26-47 \%$. At the same time, it is necessary to mention that spp. clavipes will have a chance to migrate in north-eastern direction from the current range while new areas for ssp. puniceus will be available mostly along the Alexander Archipelago and southern Alaska Peninsula. Although the process of habitat loss because of future climate change will surely depend on the combination of different environmental factors, the expected north directions of possible future migrations in Cucujus clavipes subspecies clearly suggest a crucial role of temperature. Moreover, the importance of global warming can also explain the lower values of habitat loss noted for spp. puniceus. This subspecies, compared to ssp. clavipes, can be characterized by wider geographical and particularly wider altitudinal distribution (it actually occurs up to $2300 \mathrm{~m}$ while spp. clavipes is found predominantly below $500 \mathrm{~m}$ ). As a result, the expected speed of habitat loss caused by the global warming is significantly slower for spp. puniceus as potentially it has a chance to migrate in the upper parts of the mountains. In contrast, in ssp. clavipes such a strategy can be very limited as the mountain ranges occupied by this taxon are significantly lower. None of the Cucujus clavipes subspecies is protected or listed as threatened in the USA and Canada [76], which can suggest stability of their populations and rather low impact of direct human activities on habitats occupied by these taxa including logging and forest management. On the other hand, high values of possible loss of suitable niches expected as a result of climate warming for both subspecies only during next few decades clearly suggest that we should pay more attention not only to endangered and/or protected taxa but also to common and wide-distributed species as it cannot be excluded that in near future they will need special conservation support [196]. C. clavipes seems to be a good example of species which probably will start to be threatened in the near future. We need to remember that this taxon is a part of a complex environment with hundreds or even thousands of species co-occurring in the same habitats. Although it is not possible to estimate the total number of such taxa co-occurring with ssp. clavipes and spp. puniceus along their entire ranges, one can find that only in one relatively small 
studied area in Alberta, Canada, C. clavipes puniceus was found to coexist, depending on the sampling period, together with 234-347 other beetle species and over 2000 other arthropod taxa [92,96]. Very similar results were found in southwestern Nova Scotia, Canada [97], where C. c. clavipes was noted together with 345 other beetle species. As particular subspecies can be found in great part of North America, from Alaska to California in the west, and from Quebec to Alabama in the east, and moreover, the ecological niches of both subspecies do not meet, even a cautious estimation suggests that dozens of thousand species occur together with $C$. clavipes in its entire species range.

Currently spp. clavipes and spp. puniceus are recognized as subspecies of Cucujus clavipes, but originally, they were described as separate species [86,87], which was accepted until the end of 19th century [197-199]. As it was mentioned above and based on calculation in ENMTools supporting earlier data [76], the ranges of $C$. clavipes subspecies do not overlap at any point. Moreover, literature data show that they significantly differ in morphology of adults and larvae [77] and in physiological adaptations [90,91,95,99-103], while our results prove that they can be characterized also by differences in macrohabitat preferences, phenological activity, and sensitivity for climate change. All these facts strongly suggest that taxonomical status of ssp. clavipes and ssp. puniceus should be verified by molecular data as most probably they represent separate species.

\section{Conclusions}

Studies focused on ecology of even a single species within its entire species range, especially if it is widely distributed, usually require a lot of time, big financial support for the field work as well as a large team of field workers who can collect necessary data for future analysis. With the help of citizen scientists, most of these requirements disappear or are significantly reduced at least in some types of ecological studies and in case of species which can be easily identified even by amateurs. Our study clearly suggests that the American flat bark beetle, Cucujus clavipes, which can be characterized, e.g., by unique body shape and vivid red body coloration, is a perfect model species for at least some ecological studies including actual habitat preferences and phenological activity. Moreover, we provide one more proof that citizen scientific data can be successfully used not only to analyze present-day ecological parameters of species but also allow to predict its future distribution and response on climate change. In addition, such data can be important addition to discussion about taxonomical status of the studied subspecies.

Supplementary Materials: The following are available online at https:/ / www.mdpi.com/article/10 $.3390 /$ insects12040369/s1, Data S1: Records of C. c. clavipes and C. c. puniceus accepted for this study from the iNaturalist.org database shown according to the scheme: latitude/longitude/(day.month.year). Records marked with asterisk (*) were accepted for the ENM analysis.

Author Contributions: Conceptualization, R.J.; methodology, R.J., M.K., M.M., A.S.; software, R.J., M.K., M.M., A.S.; validation, R.J., M.K., M.M., A.S.; formal analysis, R.J., M.K., M.M., A.S.; investigation, R.J.; resources, R.J.; data curation, R.J.; writing—original draft preparation, R.J., M.K., M.M., A.S.; writing-review and editing, R.J., M.K., M.M., A.S.; visualization, R.J., M.K., M.M., A.S.; supervision, R.J; project administration, R.J.; funding acquisition, R.J. All authors have read and agreed to the published version of the manuscript.

Funding: This research received no external funding. The APC was funded by the Faculty of Biology and Environmental Protection, University of Lodz, Łódź, Poland.

Institutional Review Board Statement: Not applicable.

Informed Consent Statement: Not applicable.

Data Availability Statement: Not applicable.

Acknowledgments: We would like to thank to three anonymous reviewers for their comments to the first version of manuscript and to dedicate this paper to all Citizen Scientists who helped to collect data used in this manuscript. 
Conflicts of Interest: The authors declare no conflict of interest. The funders had no role in the design of the study; in the collection, analyses, or interpretation of data; in the writing of the manuscript; or in the decision to publish the results.

\section{References}

1. Gura, T. Citizen science: Amateur experts. Nature 2013, 496, 259-261. [CrossRef]

2. Hand, E. Citizen science: People power. Nature 2010, 466, 685-687. [CrossRef]

3. Miller-Rushing, A.; Primack, R.; Bonney, R. The history of public participation in ecological research. Front. Ecol. Environ. 2012, 10, 285-290. [CrossRef]

4. Kobori, H.; Dickinson, J.L.; Washitani, I.; Sakurai, R.; Amano, T.; Komatsu, N.; Kitamura, W.; Takagawa, S.; Koyama, K.; Ogawara, T.; et al. Citizen science: A new approach to advance ecology, education and conservation. Ecol. Res. 2016, 31, 1-19. [CrossRef]

5. Richter, C.F.; Lortie, C.J.; Kelly, T.L.; Filazzola, A.; Nunes, K.A.; Sarkar, R. Online but not remote: Adapting field-based ecology laboratories for online learning. Ecol. Evol. 2020. [CrossRef]

6. Unger, S.; Rollins, M.; Tietz, A.; Dumais, H. iNaturalist as an engaging tool for identifying organisms in outdoor activities. J. Biol. Educ. 2020. [CrossRef]

7. Wilson, J.; Jisming-See, S.; Brandon-Mong, G.; Lim, A.; Lim, V.; Lee, P.; Sing, K. Citizen science: The first peninsular Malaysia butterfly count. Biodivers. Data J. 2015, 3, e7159. [CrossRef]

8. Gardiner, L.M.; Bachman, S.P. The role of citizen science in a global assessment of extinction risk in palms (Arecaceae). Bot. J Linn. Soc. 2016, 182, 543-550. [CrossRef]

9. Sumner, S.; Bevan, P.; Hart, A.G.; Isaac, N.J.B. Mapping species distributions in 2 weeks using citizen science. Insect Conserv. Divers. 2019, 12, 382-388. [CrossRef]

10. Girardello, M.; Chapman, A.; Dennis, R.; Kaila, L.; Borges, P.A.V.; Santangeli, A. Gaps in butterfly inventory data: A global analysis. Biol. Conserv. 2019, 236, 289-295. [CrossRef]

11. Skejo, J.; Gupta, S.K.; Chandra, K.; Panhwar, W.A.; Franjević, D. Oriental macropterous leaf-mimic pygmy grasshoppers-Genera Oxyphyllum and Paraphyllum (Orthoptera: Tetrigidae) and their taxonomic assignment. Zootaxa 2019, 4590, 546-560. [CrossRef] [PubMed]

12. La Sorte, F.A.; Somveille, M. The island biogeography of the eBird citizen-science programme. J. Biogeogr. 2020, 48, 628-638. [CrossRef]

13. Rose, K.; Franjević, D. Online social media tells a story of Anaselina, Paraselina, and Selivinga (Orthoptera, Tetrigidae), rare Australian pygmy grasshoppers. ZooKeys 2020, 948, 107-119. [CrossRef]

14. Webster, R.P.; de Tonnancour, P.; Sweeney, J.D.; Webster, V.L.; Kostanowicz, C.A.; Hughes, C.; Anderson, R.S.; Klymko, J.; Chantal, C.; Vigneault, R. New Coleoptera records from eastern Canada, with additions to the fauna of Manitoba, British Columbia, and Yukon Territory. ZooKeys 2020, 946, 53-112. [CrossRef]

15. Silva, D.P.; Hall, H.G.; Ascher, J.S. Predicting the distribution range of a recently described, habitat specialist bee. J. Insect Conserv. 2020, 24, 671-680. [CrossRef]

16. Jesus, M.D.; Zapelini, C.; Schiavetti, A. Can citizen science help delimit the geographical distribution of a species? The case of the Callistoctopus sp. (eastern octopus) on the Brazilian coast. Ethnobiol. Conserv. 2021, 10, 03. [CrossRef]

17. Bathori, F.; Pfliegler, W.; Zimmerman, C.-U.; Tartally, A. Online image databases as multi-purpose resources: Discovery of a new host ant of Rickia wasmannii Cavara (Ascomycota, Laboulbeniales) by screening AntWeb.org. J. Hymenopt. Res. 2017, 61, 85-94. [CrossRef]

18. Sheard, J.K.; Sanders, N.J.; Gundlach, C.; Schär, S.; Larsen, R.S. Monitoring the influx of new species through citizen science: The first introduced ant in Denmark. PeerJ 2020, 8, e8850. [CrossRef] [PubMed]

19. Skejo, J.; Deranja, M.; Adžić, K. Pygmy hunchback of New Caledonia: Notredamia dora gen. n. et sp. n.-A New Cladonotin (Caelifera: Tetrigidae) genus and species from Oceania. Entomol. News 2020, 129, 170-185. [CrossRef]

20. Hadjiconstantis, M.; Zoumides, C. First records of the pest leaf beetle Chrysolina (Chrysolinopsis) americana (Linnaeus, 1758) (Coleoptera, Chrysomelidae) in Cyprus-A study initiated from social media. Biodivers. Data J. 2021, 9, e61349. [CrossRef]

21. Hartop, E.A.; Brown, B.V.; Disney, R.H.L. Opportunity in our ignorance: Urban biodiversity study reveals 30 new species and one new nearctic record for Megaselia (Diptera: Phoridae) in Los Angeles (California, USA). Zootaxa 2015, 3941, 451-484. [CrossRef]

22. Hiller, T.; Haelewaters, D. A case of silent invasion: Citizen science confirms the presence of Harmonia axyridis (Coleoptera, Coccinellidae) in Central America. PLoS ONE 2019, 14, e0220082. [CrossRef]

23. Jaskuła, R.; Michalski, M.; Marris, J.W.M. First records of the Palaestes abruptus Sharp, 1899 and P. nicaraguae Sharp, 1899 (Coleoptera: Cucujidae) from South America, with a checklist of flat bark beetles from the continent. Biodivers. Data J. 2021, 9 , e62576. [CrossRef]

24. Alvarado-Cardenas, L.O.; Chavez-Hernandez, M.G.; Leon, J.F.P. Gonolobus naturalistae (Apocynaceae; Asclepiadoideae; Gonolobeae; Gonolobinae), a new species from Mexico. Phytotaxa 2020, 472, 249-258. [CrossRef]

25. Amorim, D.D.; Brown, B.V. Urban Scatopsidae (Diptera) of Los Angeles, California, United States. Insect Syst. Divers. $2020,4,1$. [CrossRef]

26. Adhikari, B.; Wood, J.R.I. Thunbergia kasajuana, a new species of Acanthaceae from Nepal. Kew Bull. 2020, 75, 26. [CrossRef] 
27. Cadena-Castañeda, O.J.; Díaz, C.J.A.; Rodríguez, N.O.P.; García, A.G. Studies on raspy crickets: New Triaenogryllacris species (Orthoptera: Gryllacrididae). Zootaxa 2020, 4896, 239-250. [CrossRef]

28. Moonlight, P.; Hollands, R.; Cano, A.; Purvis, D. A new species of tuberosus Begonia (Begoniaceae) from Andean Peru. Edinb. J. Bot. 2020, 77, 145-159. [CrossRef]

29. Winterton, S.L. A new bee-mimicking stiletto fly (Therevidae) from China discovered on iNaturalist. Zootaxa 2020, 4816, 361-369. [CrossRef]

30. Coxen, C.L.; Frey, J.K.; Carleton, S.A.; Collins, D.P. Species distribution models for a migratory bird based on citizen science and satellite tracking data. Glob. Ecol. Conserv. 2017, 11, 298-311. [CrossRef]

31. Schubert, S.C.; Manica, L.T.; Guaraldo, A.D. Revealing the potential of a huge citizen-science platform to study bird migration. EMU Austral Ornithol. 2019, 119, 364-373. [CrossRef]

32. DeGroote, L.W.; Hingst-Zaher, E.; Moreira-Lima, L.; Whitacre, J.V.; Slyder, J.B.; Wenzel, J. Citizen science data reveals the cryptic migration of the Common Potoo Nyctibius griseus in Brazil. Ibis 2020, 163, 380-389. [CrossRef]

33. Weisshaupt, N.; Lehtiniemi, T.; Koistinen, J. Combining citizen science and weather radar data to study large-scale bird movements. Ibis 2020, 193, 728-736. [CrossRef]

34. de Camargo Barbosa, K.V.; Develey, P.F.; Ribeiro, M.C.; Jahn, A.E. The contribution of citizen science to research on migratory and urban birds in Brazil. Ornithol. Res. 2021. [CrossRef]

35. Katušić, L.; Jelaska, S.D.; Šerić Jelaska, L. Monitoring of saproxylic beetles in Croatia: Following the path of the stag beetle. Nat. Conserv. 2017, 19, 39-56. [CrossRef]

36. Méndez, M.; de Jaime, C.; Alcántara, M.A. Habitat description and interannual variation in abundance and phenology of the endangered beetle Lucanus cervus L. (Coleoptera) using citizen science monitoring. J. Insect. Conserv. 2017, 21, 907-915. [CrossRef]

37. Zapponi, L.; Cini, A.; Bardiani, M.; Hardersen, S.; Maura, M.; Maurizi, E.; Redolfi De Zan, L.; Audisio, P.; Bologna, M.A.; Carpaneto, G.M.; et al. Citizen science data as an efficient tool for mapping protected saproxylic beetles. Biol. Conserv. 2017, 208, 139-145. [CrossRef]

38. Wilson, J.S.; Pan, A.D.; General, D.E.M.; Koch, J.B. More eyes on the prize: An observation of a very rare, threatened species of Philippine Bumble bee, Bombus irisanensis, on iNaturalist and the importance of citizen science in conservation biology. J. Insect Conserv. 2020, 24, 727-729. [CrossRef]

39. Pawson, S.M.; Sullivan, J.J.; Grant, A. Expanding general surveillance of invasive species by integrating citizens as both observers and identifiers. J. Pest Sci. 2020, 93, 1155-1166. [CrossRef]

40. Purkart, A.; Depa, Ł.; Kollár, J.; Suvák, M.; Holecová, M.; Goffová, K.; Országhová, Z. Citizen science reveals the current distribution of the new plant pest Aphis nerii in Slovakia. Plant Prot. Sci. 2020, 56, 101-106. [CrossRef]

41. Crall, A.W.; Newan, G.J.; Jarnevich, C.S.; Stohlgren, T.J.; Waller, D.M.; Graham, J. Improving and integrating data on invasive species collected by citizen scientists. Biol. Invasions 2010, 12, 3419-3428. [CrossRef]

42. Gallo, T.; Waitt, D. Creating a successful citizen science model to detect and report invasive species. BioScience 2011, 61, 459-465 [CrossRef]

43. Maistrello, L.; Dioli, P.; Bariselli, M.; Mazzoli, G.L.; Giacalone-Forini, I. Citizen science and early detection of invasive species: Phenology of first occurrences of Halyomorpha halys in Southern Europe. Biol. Invasions 2016, 18, 3109-3116. [CrossRef]

44. Goczał, K.; Rossa, R.; Sweeney, J.; Tofilski, A. Citizen monitoring of invasive species: Wing morphometry as a tool for detection of alien Tetropium species. J. Appl. Entomol. 2017, 141, 496-506. [CrossRef]

45. Mannino, A.M.; Balistreri, P. Citizen science: A successful tool for monitoring invasive alien species (IAS) in Marine Protected Areas. The case study of the Egadi Islands MPA (Tyrrhenian Sea, Italy). Biodiversity 2018, 19, 42-48. [CrossRef]

46. Roy-Dufresne, E.; Saltré, F.; Cooke, B.D.; Mellin, C.; Mutze, G.; Cox, T.; Fordham, D.A. Modeling the distribution of a wide-ranging invasive species using the sampling efforts of expert and citizen scientists. Ecol. Evol. 2019, 9, 11053-11063. [CrossRef]

47. Chen, J.Y.; McQuillan, P.B.; McDonald, E.; Hawkins, C. Citizen science reveals the Palaearctic poison hemlock moth Agonopterix alstroemeriana (Clerck) (Lepidoptera: Depressariidae) has established in Australia. N. Z. Entomol. 2020, 43, 86-92. [CrossRef]

48. Johnson, B.A.; Mader, A.D.; Dasgupta, R.; Kumar, P. Citizen science and invasive alien species: An analysis of citizen science initiatives using information and communications technology (ICT) to collect invasive alien species observations. Glob. Ecol. Conserv. 2020, 21, e00812. [CrossRef]

49. Werenkraut, V.; Baudino, F.; Roy, H.E. Citizen science reveals the distribution of the invasive harlequin ladybird (Harmonia axyridis Pallas) in Argentina. Biol. Invasions 2020, 22, 2915-2921. [CrossRef]

50. Encarnação, J.; Teodósio, M.A.; Morais, P. Citizen Science and Biological Invasions: A Review. Front. Environ. Sci. 2021, 8, 602980. [CrossRef]

51. Johansson, F.; Heino, J.; Coiffard, P.; Svanbäck, R.; Wester, J.; Bini, L.M. Can information from citizen science data be used to predict biodiversity in stormwater ponds? Sci. Rep. 2020, 10, 9380. [CrossRef]

52. Kagawa, O.; Uchida, S.; Yamazaki, D.; Osawa, Y.; Ito, S.; Chiba, S. Citizen science via social media revealed conditions of symbiosis between a marine gastropod and an epibiotic alga. Sci. Rep. 2020, 10, 19647. [CrossRef] [PubMed]

53. Nowak, K.; Berger, J.; Panikowski, A.; Reid, D.G.; Jacob, A.L.; Newman, G.; Young, N.E.; Beckmann, J.P.; Richards, S.A. Using community photography to investigate phenology: A case study of coat molt in the mountain goat (Oreamnos americanus) with missing data. Ecol. Evol. 2020, 10, 13488-13499. [CrossRef] [PubMed] 
54. Taylor, P.J.; Vise, C.; Krishnamoorthy, M.A.; Kingston, T.; Venter, S. Citizen science confirms the rarity of fruit bat pollination of baobab (Adansonia digitata) flowers in Southern Africa. Diversity 2020, 12, 106. [CrossRef]

55. Schultz, C.B.; Brown, L.M.; Pelton, E.; Crone, E.E. Citizen science monitoring demonstrates dramatic declines of monarch butterflies in western North America. Biol. Conserv. 2017, 214, 343-346. [CrossRef]

56. Bried, J.; Ries, L.; Smith, B.; Patten, M.; Abbott, J.; Ball-Damerow, J.; Cannings, R.; Cordero-Rivera, A.; Córdoba-Aguilar, A.; De Marco, P., Jr.; et al. Towards global volunteer monitoring of odonate abundance. BioScience 2020, 70, 914-923. [CrossRef]

57. Michielini, J.P.; Dopman, E.B.; Crone, E.E. Changes in flight period predict trends in abundance of Massachusetts butterflies. Ecol. Lett. 2021, 24, 249-257. [CrossRef]

58. Young, B.E.; Dodge, N.; Hunt, P.D.; Ormes, M.; Schlesinger, M.D.; Shaw, H.Y. Using citizen science data to support conservation in environmental regulatory contexts. Biol. Conserv. 2019, 237, 57-62. [CrossRef]

59. Brown, B.B.; Hunter, L.; Santos, S. Bird-window collisions: Different fall and winter risk and protective factors. PeerJ 2020, 8 , e9401. [CrossRef]

60. Duan, H.; Xia, S.; Yu, X.; Liu, Y.; Teng, J.; Dou, Y. Using citizen science data to inform the relative sensitivity of waterbirds to natural versus human-dominated landscapes in China. Ecol. Evol. 2020, 10, 7233-7241. [CrossRef] [PubMed]

61. Irga, P.J.; Dominici, L.; Torpy, F.R. The mycological social network a way forward for conservation of fungal biodiversity. Environ. Conserv. 2020, 47, 243-250. [CrossRef]

62. Margules, C.; Boedhihartono, A.K.; Langston, J.D.; Riggs, R.A.; Sari, D.A.; Sarkar, S.; Sayer, J.A.; Supriatna, J.; Winarni, N.L. Transdisciplinary science for improved conservation outcomes. Environ. Conserv. 2020, 47, 224-233. [CrossRef]

63. Papafitsoros, K.; Panagopoulou, A.; Schofield, G. Social media reveals consistently disproportionate tourism pressure on a threatened marine vertebrate. Anim. Conserv. 2020. [CrossRef]

64. Grol, M.G.G.; Vercelloni, J.; Kenyon, T.M.; Bayraktarov, E.; van den Berg, C.P.; Harris, D.; Loder, J.A.; Mihaljević, M.; Rowland, P.I.; Roelfsema, C.M. Conservation value of a subtropical reef in south-eastern Queensland, Australia, highlighted by citizen-science efforts. Mar. Freshw. Res. 2021, 72, 1-13. [CrossRef]

65. Kirchhoff, C.; Callaghan, C.T.; Keith, D.A.; Indiarto, D.; Taseski, G.; Ooi, M.K.I.; Le Breton, T.D.; Mesaglio, T.; Kingsford, R.T.; Cornwell, W.K. Rapidly mapping fire effects on biodiversity at a large-scale using citizen science. Sci. Total Environ. 2021, 755, 142348. [CrossRef] [PubMed]

66. Reed, M. Scientific citizens, smartphones and social media-Reshaping the socio-spatial networks of participation: Insects, soil and food. Morav. Geogr. Rep. 2020, 28, 61-67. [CrossRef]

67. Ciceoi, R.; Bădulescu, L.-A.; Gutue, M.; Mardare, E.Ş.; Pomohaci, C.M. Citizen-generated data on invasive alien species in Romania: Trends and challenges. Acta Zool. Bulg. 2017, 9, 255-260.

68. Spear, D.M.; Pauly, G.B.; Kaiser, K. Citizen science as a tool for augmenting museum collection data from urban areas. Front. Ecol. Evol. 2017, 5, 86. [CrossRef]

69. Heberling, J.M.; Isaac, B.L. iNaturalist as a tool to expand the research value of museum specimens. Appl. Plant Sci. 2018, 6, e1193. [CrossRef]

70. Brooks, D.R.; Nocera, J.J. Bumble bee (Bombus spp.) diversity differs between forested wetlands and clearcuts in the Acadian forest. Can. J. For. Res. 2020, 50, 1399-1404. [CrossRef]

71. Marshall, B.M.; Freed, P.; Vitt, L.; Bernardo, P.; Vogel, G.; Lotzkat, S.; Franzen, M.; Hallermann, J.; Sage, R.D.; Bush, B.; et al. An inventory of online reptile images. Zootaxa 2020, 4896, 251-264. [CrossRef] [PubMed]

72. Seregin, A.P.; Bochkov, D.A.; Shner, J.V.; Garin, E.V.; Pospelov, I.N.; Prokhorov, V.E.; Golyakov, P.V.; Mayorov, S.R.; Svirin, S.A.; Khimin, A.N.; et al. "Flora of Russia" on iNaturalist: A dataset. Biodivers. Data J. 2020, 8, e59249. [CrossRef]

73. Thomas, M.C. A revision of Pediacus Shuckard (Coleoptera: Cucujidae) for America north of Mexico, with notes on other species. Insecta Mundi 2003, 17, 157-177.

74. Lee, C.F.; Satô, M. A review of the genus Cucujus Fabricius (Insecta: Cucujoidea: Cucujidae) from Taiwan, Japan, and China, with descriptions of two new species and the larvae of Cucujus mniszechi Grouvelle. Zool. Stud. 2007, 46, 311-321.

75. Lee, C.F.; Pütz, A. A new species of Cucujus Fabricius, 1775 from China and key to the east-Palaearctic species of the genus (Coleoptera: Cucujidae). Entomol. Z. 2008, 118, 211-213.

76. Horák, J.; Chobot, K. Worldwide distribution of saproxylic beetles of the genus Cucujus Fabricius, 1775 (Coleoptera: Cucujidae). In Proceedings of the 5th Symposium and Workshop on the Conservation of Saproxylic Beetles, Lüneberg, Germany, 14-16 June 2008; Buse, J., Alexander, K., Ranius, T., Assmann, T., Eds.; Pensoft Publishers: Moscow, Russia, 2009; pp. 189-206, ISBN 97895464250722.

77. Lee, J.; Thomas, M.C. Clarification of the taxonomic status of Cucujus clavipes with descriptions of the larvae of C. c. clavipes and C. c. puniceus (Coleoptera: Cucujidae). Fla. Entomol. 2011, 94, 145-150. [CrossRef]

78. Bonacci, T.; Mazzei, A.; Horák, J.; Brandmayr, P. Cucujus tulliae sp. n.-An endemic Mediterranean saproxylic beetle from genus Cucujus Fabricius, 1775 (Coleoptera, Cucujidae), and keys for identification of adults and larvae native to Europe. ZooKeys 2012, 212, 63-79. [CrossRef]

79. Marris, J.W.M.; Ślipiński, A. A revision of the Pediacus Shuckard 1839 (Coleoptera: Cucujidae) of Asia and Australasia. Zootaxa 2014, 3754, 32-58. [CrossRef]

80. Bussler, H. Cucujus muelleri sp. n. aus den kaspischen Gebirgswaldern des Iran (Coleoptera: Cucujidae). Nachr. Der Bayer. Entomol. 2017, 66, 54-58. 
81. Marris, J.W.M. A revision of the flat bark beetle genus Platisus Erichson, 1842 (Coleoptera: Cucujidae). Austral Entomol. 2017, 56, 277-295. [CrossRef]

82. Háva, J.; Zahradník, P.; Růžička, T. A new species of genus Cucujus Fabricius, 1775 (Coleoptera: Cucujidae) from China. Nat. Som. 2019, 33, 129-134. [CrossRef]

83. Zhao, M.-Z.; Zhang, J.-K. Contribution to the knowledge of the genus Cucujus Fabricius (Coleoptera, Cucujidae) from China. Zootaxa 2019, 4544, 144-150. [CrossRef] [PubMed]

84. Jin, M.; Zwick, A.; Ślipiński, A.; Marris, J.W.M.; Thomas, M.C.; Pang, H. A comprehensive phylogeny of flat bark beetles (Coleoptera: Cucujidae) with a revised classification and a new South American genus. Syst. Entomol. 2020, 45, 248-268. [CrossRef]

85. Jaskuła, R.; Michalski, M.; Acal, D.A. First record of the family Cucujidae (Insecta: Coleoptera) from Vietnam with a checklist and a key to species currently known from Indochinese Peninsula. Orient. Insects 2020. [CrossRef]

86. Fabricius, J.C. Species Insectorum, Exhibentes Eorum Differentias Specificas, Synonyma Auctorum, Loca Natalia, Metamorphosin, Adjectis Observationibus, Descriptionibus; Tom. 1. C. E. Bohnii, Hamburg-Kiel; NCSU Libraries: Raleigh, NC, USA, 1781; p. 566. [CrossRef]

87. Mannercheim, G.C.G. Beitrag zur Kaefer-Fauna der Aleutischen Inseln, der Inseln Sitkha und Neu-Californiens. Bull. De La Société Impériale Des Nat. De Moscou 1843, 16, 175-314.

88. DeLeon, D. An annotated list of the parasites, predators, and other associated fauna of the mountain pine beetle in western white pine and lodgepole pine. Can. Entomol. 1934, 66, 51-61. [CrossRef]

89. Smith, D.B.; Sears, M.K. Mandibular structure and feeding habits of the morphologically similar coleopterous larvae: Cucujus clavipes (Cucujidae), Dendroides canadensis (Pyrochroidae) and Pytho depressus (Salpingidae). Can. Entomol. 1982, 114, 173-175. [CrossRef]

90. Duman, J.G. Chance in overwintering mechanism of the cucujid beetle, Cucujus clavipes. J. Insect Physiol. 1984, 30, 235-239. [CrossRef]

91. Kukal, J.G.; Duman, J.G. Switch in the overwintering strategy of two insect species and latitudinal differences in cold hardiness. Can. J. Zool. 1989, 67, 825-827. [CrossRef]

92. Hammond, H.E.J. Arthropod biodiversity from Populus coarse woody material in north-central Alberta: A review of taxa and collection methods. Can. Entomol. 1997, 129, 1009-1033. [CrossRef]

93. Hammond, J.H.E.; Langor, D.W.; Spence, J.R. Early colonization of Populus wood by saproxylic beetles (Coleoptera). Can. J. For. Res. 2001, 31, 1175-1183. [CrossRef]

94. Kennedy, A.A.; McCullough, D.G. Phenology of the larger European pine shoot beetle Tomicus piniperda (L.) (Coleoptera: Scolytidae) in relation to native bark beetles and natural enemies in pine stands. Environ. Entomol. 2002, 31, 261-272. [CrossRef]

95. Bennett, V.A.; Sformo, T.; Walters, K.; Toien, O.; Jeannet, K.; Hochstrasser, R.; Pan, Q.; Serianni, A.S.; Barnes, B.M.; Duman, J.G. Comparative overwintering physiology of Alaska and Indiana populations of the beetle Cucujus clavipes (Fabricius): Roles of antifreeze proteins, polyols, dehydration and diapause. J. Exp. Biol. 2005, 208, 4467-4477. [CrossRef] [PubMed]

96. Jacobs, J.M.; Spence, J.R.; Langor, D.W. Influence of boreal forest succession and dead wood qualities on saproxylic beetles. Agric. For. Entomol. 2007, 9, 3-16. [CrossRef]

97. Dollin, P.E.; Majka, C.G.; Duinker, P.N. Saproxylic beetle (Coleoptera) communities and forest management practices in coniferous stands in southwestern Nova Scotia, Canada. ZooKeys 2008, 2, 291-336. [CrossRef]

98. Majka, C.G. The flat bark beetles (Coleoptera: Silvanidae, Cucujidae, Laemophloeidae) of Atlantic Canada. ZooKeys 2008, 2, 221-238. [CrossRef]

99. Sformo, T.; Walters, K.; Jeannet, K.; Wowk, B.; Fahy, G.M.; Barnes, B.M.; Duman, J.G. Deep supercooling, vitrification and limited survival to $-100^{\circ} \mathrm{C}$ in the Alaskan beetle Cucujus clavipes puniceus (Coleoptera: Cucujidae) larvae. J. Exp. Biol. 2010, 213, 502-509. [CrossRef] [PubMed]

100. Carrasco, M.A.; Buechler, S.A.; Arnold, R.A.; Sformo, T.; Barnes, B.M.; Duman, J.G. Elucidating the biochemical overwintering adaptations of larval Cucujus clavipes puniceus, a nonmodel organism, via high throughput proteomics. J. Proteome Res. 2011, 10, 4634-4646. [CrossRef]

101. Sformo, T.; McIntyre, J.; Walters, K.R., Jr.; Barnes, B.M.; Duman, J. Probability of freezing in the freeze-avoiding beetle larvae Cucujus clavipes puniceus (Coleoptera: Cucujidae) from interior Alaska. J. Insect Physiol. 2011, 57, 1170-1177. [CrossRef]

102. Carrasco, M.A.; Buechler, S.A.; Arnold, R.A.; Sformo, T.; Barnes, B.M.; Duman, J.G. Investigating the deep supercooling ability of an Alaskan beetle, Cucujus clavipes puniceus, via high throughput proteomics. J. Proteome Res. 2012, 75, 1220-1234. [CrossRef] [PubMed]

103. Vu, H.M.; Duman, J.G. Upper lethal temperatures in three cold-tolerant insects are higher in winter than in summer. J. Exp. Biol. 2017, 220, 2726-2732. [CrossRef]

104. Hsiao, Y. A taxonomic study of Cucujus Fabricius, 1775 from Asia (Coleoptera: Cucujidae), with descriptions of new species and notes on morphological classification. Insect Syst. Evol. 2020. [CrossRef]

105. Tozer, B.; Sandwell, D.T.; Smith, W.H.F.; Olson, C.; Beale, J.R.; Wessel, P. Global bathymetry and topography at 15 arc sec: SRTM15+. Earth Space Sci. 2019, 6, 1847-1864. [CrossRef]

106. R Core Team. R: A Language and Environment for Statistical Computing; R Foundation for Statistical Computing: Vienna, Austria, 2020. Available online: https:/ / www.R-project.org/ (accessed on 20 January 2021). 
107. Wickham, H. ggplot2: Elegant Graphics for Data Analysis; Springer: New York, NY, USA, 2016. Available online: https://ggplot2 .tidyverse.org (accessed on 20 January 2021).

108. Ter Braak, C.J.F. CANOCO-A FORTRAN Program for Canonical Community Ordination by [Partial][Detrended][Canonical] Correspondence Analysis, Principal Components Analysis and Redundancy Analysis (Version 2.1); DLO Agricultural Mathematics Group: Wageningen, The Netherlands, 1987; p. 95.

109. Ter Braak, C.J.F.; Šmilauer, P. CANOCO Reference Manual and CanoDraw for Windows User's Guide: Software for Canonical Community Ordination (Version 4.5); Microcomputer Power: Ithaca, NY, USA, 2002; p. 499.

110. Brown, J.L. SDMtoolbox: A python-based GIS toolkit for landscape genetic, biogeographic and species distribution model analyses. Methods Ecol. Evol. 2014, 5, 694-700. [CrossRef]

111. Phillips, S.J.; Dudík, M.; Schapire, R.E. A maximum entropy approach to species distribution modeling. ICML '04. In Proceedings of the Twenty-First International Conference on Machine Learning, Banff, Canada, 4-8 July 2004; ACM: New York, NY, USA, 2004; pp. 655-662. [CrossRef]

112. Phillips, S.J.; Anderson, R.; Schapire, R.E. Maximum entropy modeling of species geographic distributions. Ecol. Model. 2006, 190, 231-259. [CrossRef]

113. Elith, J.; Phillips, S.J.; Hastie, T.; Dudík, M.; Chee, Y.E.; Yates, C.J. A statistical explanation of MaxEnt for ecologists. Divers. Distrib. 2011, 17, 43-57. [CrossRef]

114. Fick, S.E.; Hijmans, R.J. WorldClim 2: New $1 \mathrm{~km}$ spatial resolution climate surfaces for global land areas. Int. J. Climatol. 2017, 37, 4302-4315. [CrossRef]

115. Hengl, T.; de Jesus, J.M.; MacMillan, R.A.; Batjes, N.H.; Heuvelink, G.B.M.; Ribeiro, E.; Samuel-Rosa, A.; Kempen, B.; Leenaars, J.G.B.; Walsh, M.G.; et al. SoilGrids1km—Global Soil Information Based on Automated Mapping. PLoS ONE 2014, 9 , e105992. [CrossRef] [PubMed]

116. Barve, N.; Barve, V.; Jimenez-Valverde, A.; Lira-Noriega, A.; Maher, S.P.; Peterson, A.T.; Soberón, J.; Villalobos, F. The crucial role of the accessible area in ecological niche modeling and species distribution modeling. Ecol. Mod. 2011, 222, 1810-1819. [CrossRef]

117. O’Neill, B.C.; Kriegler, E.; Riahi, K.; Ebi, K.L.; Hallegatte, S.; Carter, T.R.; Mathur, R.; van Vuuren, D.P. A new scenario frame-work for climate change research: The concept of shared socioeconomic pathways. Clim. Chang. 2014, 122, 387-400. [CrossRef]

118. Phillips, S.B.; Aneja, V.P.; Kang, D.; Arya, S.P. Modelling and analysis of the atmospheric nitrogen deposition in North Carolina. Int. J. Glob. Environ. Issues 2006, 6, 231-252. [CrossRef]

119. Mason, S.J.; Graham, N.E. Areas beneath the relative operating characteristics (ROC) and relative operating levels (ROL) curves statistical significance and interpretation. Q. J. R. Meteorol. Soc. 2002, 128, 2145-2166. [CrossRef]

120. Evangelista, P.H.; Kumar, S.; Stohlgren, T.J.; Jarnevich, C.S.; Crall, A.W.; Norman III, J.B.; Barnett, D.T. Modelling invasion for a habitat generalist and a specialist plant species. Divers Distrib. 2008, 14, 808-817. [CrossRef]

121. Allouche, O.; Tsoar, A.; Kadmon, R. Assessing the accuracy of species distribution models: Prevalence, kappa and the true skill statistic (TSS). J. Appl. Ecol. 2006, 43, 1223-1232. [CrossRef]

122. Horák, J.; Chobot, K. Phenology and notes on the behaviour of Cucujus cinnaberinus: Points for understanding the conservation of the saproxylic beetle. North-West. J. Zool. 2011, 7, 352-355.

123. Marczak, D. Zgniotek cynobrowy Cucujus cinnaberinus w Kampinoskim Parku Narodowym i uwagi do jego monitoringu. Studia $i$ Materiaty CEPL w Rogowie 2016, 49A, 142-152.

124. Bale, J.S.; Masters, G.J.; Hodkinson, I.D.; Amack, C.; Bezemer, T.M.; Brown, V.K.; Butterfield, J.; Buse, A.; Coulson, J.C.; Farrar, J.; et al. Herbivory in global climate change research: Direct effects of rising temperature on insect herbivores. Glob. Chang. Biol. 2002, 8, 1-16. [CrossRef]

125. Menéndez, R. How are insects responding to global warming. Tijdschr. Voor Entomol. 2007, 150, $355-365$.

126. Lieth, H. (Ed.) Phenology and Seasonality Modeling. Ecological Studies Series; Springer: New York, NY, USA, $1974 ;$ p. 444.

127. Tauber, M.J.; Tauber, C.A. Insect seasonality: Diapause maintenance, termination, and postdiapause development. Annu. Rev. Entomol. 1976, 21, 81-107. [CrossRef]

128. Denno, R.F.; Dingle, H. Insect Life History Patterns: Habitat and Geographic Variation; Springer: New York, NY, USA, 1981 ; p. 225.

129. Brown, V.K.; Hodek, I. (Eds.) Diapause and Life Cycle Strategies in Insects; W. Junk Publisher: Berlin, Germany, $1983 ;$ p. 283.

130. Scott, J.A.; Epstein, M.E. Factors affecting phenology in a temperate insect community. Am. Midl. Nat. 1987, 117, 103-118. [CrossRef]

131. Alonso, C. Variation in herbivory by Yponomeuta mahalebella on its only host plant Prunus mahaleb along an elevational gradient. Ecol. Entomol. 1999, 24, 371-379. [CrossRef]

132. Hodkinson, I.D. Terrestrial insects along elevations gradients. Biol. Rev. 2005, 80, 489-513. [CrossRef] [PubMed]

133. Lazzari, S.M.N.; Lazzarotto, C.M. Distribuição altitudinal e sazonal de afídeos (Hemiptera, Aphididae) na Serra do Mar, Paraná, Brasil. Rev. Bras. De Zool. 2005, 22, 891-897. [CrossRef]

134. Merrill, R.M.; Gutiérrez, D.; Lewis, O.T.; Gutiérrez, J.; Díez, S.B.; Wilson, R.J. Combined effects of climate and biotic interactions on the elevational range of a phytophagous insect. J. Anim. Ecol. 2008, 77, 145-155. [CrossRef] [PubMed]

135. Buchholz, L. Zgniotek cynobrowy Cucujus cinnaberinus (Scopoli, 1763). In Monitoring Gatunków Zwierzat. Przewodnik Metodyczny. Część Druga; Makomaska-Juchewicz, M., Baran, P., Eds.; Biblioteka Monitoringu Środowiska, Inspekcja Ochrony Środowiska: Kraków, Poland, 2012; pp. 419-446, 522. 
136. Parmesan, C.; Ryrholm, N.; Stefanescu, C.; Hill, J.K.; Thomas, C.D.; Descimon, H.; Huntley, B.; Kaila, L.; Kullberg, J.; Tammaru, T.; et al. Poleward shifts in geographical ranges of butterfly species associated with regional warming. Nature 1999, 399, 579-583. [CrossRef]

137. Roy, D.B.; Sparks, T.H. Phenology of British butterflies and climate change. Glob. Chang. Biol. 2000, 6, 407-416. [CrossRef]

138. Forister, M.L.; Shapiro, A.M. Climatic trends and advancing spring flight of butterflies in lowland California. Glob. Chang. Biol. 2003, 9, 1130-1135. [CrossRef]

139. Bartomeus, I.; Ascher, J.S.; Wagner, D.; Danforth, B.N.; Colla, S.; Kornbluth, S.; Winfree, R. Climate-associated phenological advances in bee pollinators and bee-pollinated plants. Proc. Natl. Acad. Sci. USA 2011, 108, 20654-20659. [CrossRef] [PubMed]

140. Diamond, S.E.; Frame, A.M.; Martin, R.A.; Buckley, L.B. Species' traits predict phenological responses to climate change in butterflies. Ecology 2011, 92, 1005-1012. [CrossRef]

141. Guo, K.; Sun, O.J.; Kang, L. The responses of insects to global warming. In Recent Advances in Entomological Research; Liu, T., Kang, L., Eds.; Springer: Berlin/Heidelberg, Germany, 2011. [CrossRef]

142. Brooks, S.J.; Self, A.; Toloni, F.; Sparks, T. Natural history museum collections provide information on phenological change in British butterflies since the late-nineteenth century. Int. J. Biometeorol. 2014, 58, 1749-1758. [CrossRef]

143. Kharouba, H.M.; Paquette, S.R.; Kerr, J.T.; Vellend, M. Predicting the sensitivity of butterfly phenology to temperature over the past century. Glob. Chang. Biol. 2014, 20, 504-514. [CrossRef]

144. Bell, J.R.; Alderson, L.; Izera, D.; Kruger, T.; Parker, S.; Pickup, J.; Shortall, C.R.; Taylor, M.S.; Verrier, P.; Harrington, R. Long-term phenological trends, species accumulation rates, aphid traits and climate: Five decades of change in migrating aphids. J. Anim. Ecol. 2015, 84, 21-34. [CrossRef]

145. Sato, Y.; Sato, S. Spring Temperature Predicts the Long-term Molting Phenology of Two Cicadas, Cryptotympana facialis and Graptopsaltria nigrofuscata (Hemiptera: Cicadidae). Ann. Entomol. Soc. Am. 2015, 108, 494-500. [CrossRef]

146. Forrest, J.R.K. Complex responses of insect phenology to climate change. Curr. Opin. Insect Sci. 2016, 17, 49-54. [CrossRef]

147. Thomsen, P.F.; Jørgensen, P.S.; Bruun, H.H.; Pedersen, J.; Riis-Nielsen, T.; Jonko, K.; Słowińska, I.; Rahbek, C.; Karsholt, O. Resource specialists lead local insect community turnover associated with temperature-Analysis of an 18-year full-seasonal record of moths and beetles. J. Anim. Ecol. 2016, 85, 251-261. [CrossRef] [PubMed]

148. Pureswaran, D.S.; Roques, A.; Battisti, A. Forest Insects and Climate Change. Curr. For. Rep. 2018, 4, 35-50. [CrossRef]

149. Lehmann, P.; Ammunét, T.; Barton, M.; Battisti, A.; Eigenbrode, S.D.; Jepsen, J.U.; Kalinkat, G.; Neuvonen, S.; Niemelä, P.; Terblanche, J.S.; et al. Complex responses of global insect pests to climate warming. Front. Ecol. Environ. 2020, 18, 141-150. [CrossRef]

150. Thomas, M.C. Family 82. Cucujidae Latreille 1802. In American Beetles: Polyphaga: Scarabaeoidea through Cuculionoidea; Arnett, R.H., Jr., Thomas, M.C., Skelley, P.E., Frank, J.H., Eds.; CRC Press: Boca Raton, FL, USA, 2002; Volume 2, pp. 329-330.

151. Evans, A.V.; Hogue, J.N. Field Guide to Beetles of California, Flat Bark Beetles (Cucujidae); University of California Press: Berkeley, CA, USA; Los Angeles, CA, USA; London, UK, 2006.

152. Horák, J.; Chobot, K.; Kohutka, A.; Gebauer, R. Possible factors influencing distribution of a threatened saproxylic beetle Cucujus cinnaberinus (Scopoli, 1763) (Coleoptera: Cucujidae). Coleopt. Bull. 2008, 62, 437-440. [CrossRef]

153. Horák, J.; Vávrová, E.; Chobot, K. Habitat preferences influencing populations, distribution and conservation of the endangered saproxylic beetle Cucujus cinnaberinus (Coleoptera: Cucujidae) at the landscape level. Eur. J. Entomol. 2010, 107, 81-88. [CrossRef]

154. Mazzei, A.; Bonacci, T.; Contarini, E.; Zetto, T.; Brandmayr, P. Rediscovering the 'umbrella species' candidate Cucujus cinnaberinus (Scopoli, 1763) in Southern Italy (Coleoptera Cucujidae), and notes on bionomy. Ital. J. Zool. 2011, 78, 264-270. [CrossRef]

155. Horák, J.; Chumanová, E.; Hilszczański, J. Saproxylic beetle thrives on the openness in management: A case study on the ecological requirements of Cucujus cinnaberinus from Central Europe. Insect Conserv. Divers. 2012, 5, 403-413. [CrossRef]

156. Goczał, J.; Rossa, R. Dead wood complexity shapes the pattern of the occurrence of threatened saproxylic beetle Cucujus cinnaberinus. Pol. J. Ecol. 2017, 65, 158-165. [CrossRef]

157. Vrezec, A.; Ambrožič, S.; Kobler, A.; Kapla, A.; de Groot, M. Cucujus cinnaberinus (Scopoli, 1763) at its terra typica in Slovenia: Historical overview, distribution patterns and habitat selection. Nat. Conserv. 2017, 19, 219-229. [CrossRef]

158. Bełcik, M.; Goczał, L.; Ciach, M. Large-scale habitat model reveals a key role of large trees and protected areas in the metapopulation survival of the saproxylic specialist Cucujus Cinnaberinus. Biodivers. Conserv. 2018, 28, 3851-3871. [CrossRef]

159. Bonacci, T.; Mazzei, A.; Naccarato, A.; Elliani, R.; Tagarelli, A.; Brandmayr, P. Beetles "in red": Are the endangered flat bark beetles Cucujus cinnaberinus and C. haematodes chemically protected? (Coleoptera: Cucujidae). Eur. Zool. J. 2018, 85, 129-137. [CrossRef]

160. Bonacci, T.; Rovito, M.; Horák, J.; Brandmayr, P. Artificial Feeding and Laboratory Rearing of Endangered Saproxylic Beetles as a Tool for Insect Conservation. J. Insect Sci. 2020, 20, 1-7. [CrossRef] [PubMed]

161. Barnosky, A.D.; Matzke, N.; Tomiya, S.; Wogan, G.O.U.; Swarts, B.; Quental, T.B.; Marshall, C.; McGuire, J.L.; Lindsey, E.L.; Maguire, K.C.; et al. Has the Earth's sixth mass extinction already arrived? Nature 2011, 471, 51-57. [CrossRef]

162. Ceballos, G.; Ehrlich, P.R.; Barnosky, A.D.; García, A.; Pringle, R.M.; Palmer, T.M. Accelerated modern human-induced species losses: Entering the sixth mass extinction. Sci. Adv. 2015, 1, e1400253. [CrossRef]

163. Ceballos, G.; Ehrlich, P.R.; Dirzo, R. Biological annihilation via the ongoing sixth mass extinction signaled by vertebrate population losses and declines. Proc. Natl. Acad. Sci. USA 2017, 114, E6089-E6096. [CrossRef] 
164. Hughes, L. Biological consequences of global warming: Is the signal already apparent? Trends Ecol. Evol. $2000,15,56-61$. [CrossRef]

165. Walther, G.-R.; Post, E.; Convey, P.; Menzel, A.; Parmesan, C.; Beebee, T.J.C.; Fromentin, J.-M.; Hoegh-Guldberg, O.; Bairlein, F. Ecological responses to recent climate change. Nature 2002, 416, 389-395. [CrossRef]

166. Parmesan, C.; Yohe, G. A globally coherent fingerprint of climate change impacts across natural systems. Nature 2003, 421, 37-42. [CrossRef] [PubMed]

167. Root, T.L.; Price, J.T.; Hall, K.R.; Schneider, S.H.; Rosenzweig, C.; Pounds, J.A. Fingerprints of global warming on wild animals and plants. Nature 2003, 421, 57-60. [CrossRef] [PubMed]

168. Thomas, C.D.; Cameron, A.; Green, R.E.; Bakkenes, M.; Beaumont, L.J.; Collingham, Y.C.; Erasmus, B.F.N.; de Siqueira, M.F.; Grainger, A.; Hannah, L.; et al. Extinction risk from climate change. Nature 2004, 427, 145-148. [CrossRef]

169. Walther, G.-R.; Beißner, S.; Burga, C.A. Trends in the upward shift of alpine plants. J. Veg. Sci. 2005, 16, 541-548. [CrossRef]

170. Menzel, A.; Sparks, T.H.; Estrella, N.; Koch, E.; Aasa, A.; Ahas, R.; Alm-Kübler, K.; Bissolli, P.; Braslavská, O.; Briede, A.; et al. European phenological response to climate change matches the warming pattern. Glob. Chang. Biol. 2006, 12, 1969-1976. [CrossRef]

171. Parmesan, C. Ecological and evolutionary responses to recent climate change. Ann. Rev. Ecol. Evol. Syst. 2006, 37, 637-669. [CrossRef]

172. Lenoir, J.; Gégout, J.C.; Marquet, P.A.; de Ruffray, P.; Brisse, H. A Significant Upward Shift in Plant Species Optimum Elevation During the 20th Century. Science 2008, 320, 1768-1771. [CrossRef]

173. Schweiger, O.; Biesmeijer, J.C.; Bommarco, R.; Hickler, T.; Hulme, P.E.; Klotz, S.; Kühn, I.; Moora, M.; Nielsen, A.; Ohlemüller, R.; et al. Multiple stressors on biotic interactions: How climate change and alien species interact to affect pollination. Biol. Rev. 2010, 85, 777-795. [CrossRef]

174. Bellard, C.; Bertelsmeier, C.; Leadley, P.; Thuiller, W.; Courchamp, F. Impacts of climate change on the future of biodiversity. Ecol. Lett. 2012, 15, 365-377. [CrossRef]

175. Rasmont, P.; Franzén, M.; Lecocq, T.; Harpke, A.; Roberts, S.; Biesmeijer, J.; Castro, L.; Cederberg, B.; Dvorak, L.; Fitzpatrick, Ú.; et al. Climatic risk and distribution atlas of European bumblebees. BioRisk 2015, 10, 1-236. [CrossRef]

176. Pecl, G.T.; Araújo, M.B.; Bell, J.D.; Blanchard, J.; Bonebrake, T.C.; Chen, I.-C.; Clark, T.D.; Colwell, R.K.; Danielsen, F.; Evengård, B.; et al. Biodiversity redistribution under climate change: Impacts on ecosystems and human well-being. Science 2017, 355, eaai9214. [CrossRef] [PubMed]

177. Varela, S.; Lobo, J.M.; Hortal, J. Using species distribution models in paleobiogeography: A matter of data, predictors and concepts. Palaeogeogr. Palaeoclim.. Palaeoecol. 2011, 310, 451-463. [CrossRef]

178. Lima-Ribeiro, M.S.; Varela, S.; Nógues-Bravo, D.; Diniz-Filho, J.A.F. Potential suitable areas of Giant Ground Sloths dropped before its extinction in South America: The evidences from bioclimatic envelope modelling. Nat. Conserv. 2012, 10, 145-151. [CrossRef]

179. Barrientos, R.; Kvist, L.; Barbosa, A.; Valera, F.; Khoury, F.; Varela, S.; Moreno, E. Refugia, colonization and diversification of an arid-adapted bird: Coincident patterns between genetic data and ecological niche modelling. Mol. Ecol. 2014, 23, 390-407. [CrossRef] [PubMed]

180. Kukwa, M.; Kolanowska, M. Glacial refugia and the prediction of future habitat coverage of the South American lichen species Ochrolechia austroamericana. Sci. Rep. 2016, 6, 38779. [CrossRef]

181. Biella, P.; Bogliani, G.; Cornalba, M.; Manino, A.; Neumayer, J.; Porporato, M.; Rasmont, P.; Milanesi, P. Distribution patterns of the cold adapted bumblebee Bombus alpinus in the Alps and hints of an uphill shift (Insecta: Hymenoptera: Apidae). J. Insect Conserv. 2017, 21, 357-366. [CrossRef]

182. Wilson, C.D.; Roberts, D.; Reid, N. Applying species distribution modeling to identify areas of high conservation value for endangered species: A case study using Margaritifera margaritifera (L.). Biol. Conserv. 2011, 144, 821-829. [CrossRef]

183. Koch, R.; Almeida-Cortez, J.S.; Kleinschmit, B. Revealing areas of high nature conservation importance in a seasonally dry tropical forest in Brazil: Combination of modelled plant diversity hot spots and threat patterns. J. Nat. Conserv. 2017, 35, 24-39. [CrossRef]

184. Spiers, J.A.; Oatham, M.P.; Rostant, L.V.; Farrell, A.D. Applying species distribution modelling to improving conservation based decisions: A gap analysis of Trinidad and Tobago's endemic vascular plants. Biodivers. Conserv. 2018, 27, 2931-2949. [CrossRef]

185. Nóbrega, C.C.; De Marco, P., Jr. Unprotecting the rare species: A niche-based gap analysis for odonates in a core Cerrado area. Divers. Distrib. 2011, 17, 491-505. [CrossRef]

186. Silva, D.P.; Aguiar, A.J.C.; Melo, G.A.R.; Anjos-Silva, E.J.; De Marco, P., Jr. Amazonian species within the Cerrado savanna: New records and potential distribution for Aglae caerulea (Apidae: Euglossini). Apidologie 2013, 44, 673-683. [CrossRef]

187. Estay, S.A.; Labra, F.A.; Sepulveda, R.D.; Bacigalupe, L.D. Evaluating Habitat Suitability for the Establishment of Monochamus spp. through Climate-Based Niche Modeling. PLoS ONE 2014, 9, e102592. [CrossRef] [PubMed]

188. Pérez-De la, O.N.B.; Espinosa-Zaragoza, S.; López-Martínez, V.; Hight, S.D.; Varone, L. Ecological niche modeling to calculate ideal sites to introduce a natural enemy: The case of Apanteles opuntiarum (Hymenoptera: Braconidae) to control Cactoblastis cactorum (Lepidoptera: Pyralidae) in North America. Insects 2020, 11, 454. [CrossRef] [PubMed]

189. Raxworthy, C.; Martinez-Meyer, E.; Horning, N.; Nussbaum, R.A.; Schneider, G.E.; Ortega-Huerta, M.A.; Peterson, A.T. Predicting distributions of known and unknown reptile species in Madagascar. Nature 2003, 426, 837-841. [CrossRef] 
190. Silva, D.P.; Andrade, A.F.A.; Oliveira, J.P.J.; Morais, D.M.; Vieira, J.E.A.; Engel, M.S. Current and future ranges of an elusive North American insect using species distribution models. J. Insect Conserv. 2019, 23, 175-186. [CrossRef]

191. Rödder, D.; Schmidtlein, S.; Veith, M.; Lötters, S. Alien invasive slider turtle in unpredicted habitat: A matter of niche shift or of predictors studied? PLoS ONE 2009, 4, e7843. [CrossRef] [PubMed]

192. Gallien, L.; Muenkemueller, T.; Albert, C.H.; Boulangeat, I.; Thuiller, W. Predicting potential distributions of invasive species: Where to go from here? Divers. Distrib. 2010, 16, 331-342. [CrossRef]

193. Hortal, J.; Roura-Pascual, N.; Sanders, N.J.; Rahbek, C. Understanding (insect) species distributions across spatial scales. Ecography 2010, 33, 51-53. [CrossRef]

194. Kolanowska, M.; Konowalik, K. Niche conservatism and future changes in the potential area coverage of Arundina graminifolia, an invasive orchid species from Southeast Asia. Biotropica 2014, 46, 157-165. [CrossRef]

195. Olivera, L.; Minghetti, E.; Montemayor, S. Ecological niche modeling (ENM) of Leptoglossus clypealis a new potential global invader: Following in the footsteps of Leptoglossus occidentalis? Bull. Entomol. Res. 2020, 1-12. [CrossRef] [PubMed]

196. Martins, A.C.; Silva, D.P.; De Marco Jr, P.; Melo, G.A.R. Species conservation under future climate change: The case of Bombus bellicosus, a potentially threatened South American bumblebee species. J. Insect Conserv. 2015, 19, 33-43. [CrossRef]

197. LeConte, J.L. Synopsis of the Cucujides of the United States. Proc. Acad. Nat. Sci. Phila. 1854, 7, 73-79.

198. LeConte, J.L. Classification of the Coleoptera of North America. Prepared for the Smithsonian Institution. Part 1. Smithson. Misc. Collect. 1861, 136, 286.

199. LeConte, J.L. List of the Coleoptera of North America. Prepared for the Smithsonian Institution. Part 1. Smithson. Misc. Collect. $1863,140,77$. 